\title{
Arbeidsmarktindicatoren ten behoeve van het emancipatiebeleid aan de Rijksuniversiteit Limburg
}

Citation for published version (APA):

Lodder, B. J. H., van de Loo, P., Ramaekers, G. W. M., \& van der Velden, R. K. W. (1991).

Arbeidsmarktindicatoren ten behoeve van het emancipatiebeleid aan de Rijksuniversiteit Limburg. Researchcentrum voor Onderwijs en Arbeidsmarkt, Faculteit der Economische Wetenschappen. ROA Reports No. 7 https://doi.org/10.26481/umarep.1991007

Document status and date:

Published: 01/01/1991

DOI:

10.26481/umarep.1991007

Document Version:

Publisher's PDF, also known as Version of record

\section{Please check the document version of this publication:}

- A submitted manuscript is the version of the article upon submission and before peer-review. There can be important differences between the submitted version and the official published version of record.

People interested in the research are advised to contact the author for the final version of the publication, or visit the DOI to the publisher's website.

- The final author version and the galley proof are versions of the publication after peer review.

- The final published version features the final layout of the paper including the volume, issue and page numbers.

Link to publication

\footnotetext{
General rights rights.

- You may freely distribute the URL identifying the publication in the public portal. please follow below link for the End User Agreement:

www.umlib.nl/taverne-license

Take down policy

If you believe that this document breaches copyright please contact us at:

repository@maastrichtuniversity.nl

providing details and we will investigate your claim.
}

Copyright and moral rights for the publications made accessible in the public portal are retained by the authors and/or other copyright owners and it is a condition of accessing publications that users recognise and abide by the legal requirements associated with these

- Users may download and print one copy of any publication from the public portal for the purpose of private study or research.

- You may not further distribute the material or use it for any profit-making activity or commercial gain

If the publication is distributed under the terms of Article $25 \mathrm{fa}$ of the Dutch Copyright Act, indicated by the "Taverne" license above, 
ARBEIDSMARKTINDICATOREN TEN BEHOEVE VAN HET EMANCIPATIEBELEID AAN DE RIJKSUNIVERSITEIT LIMBURG

ROA-R-1991/7

B.J.H. Lodder

P.J.E. van de Loo

G.W.M. Ramaekers

R.K.W. van der Velden

RESEARCHCENTRUM VOOR ONDERWIJS EN ARBEIDSMARKT

Faculteit der Economische Wetenschappen

Rijksuniversiteit Limburg

Maastricht, september 1991 
CIP-GEGEVENS KONINKLIJKE BIBLIOTHEEK, DEN HAAG

Arbeidsmarktindicatoren

Arbeidsmarktindicatoren ten behoeve van het emancipatiebeleid aan de Rijksuniversiteit Limburg / B.J.H. Lodder ... [et al.]. - Maastricht : Researchcentrum voor Onderwijs en Arbeidsmarkt, Faculteit der Economische Wetenschappen, Rijksuniversiteit Limburg. - Tab.

Met lit. opg.

ISBN 90-5321-061-X geb.

Trefw.: emancipatiebeleid en arbeidsmarkt ; Nederland. 


\section{INHOUDSOPGAVE}

2. SEXEDISCREPANTIES OP DE LANDELIJKE ARBEIDSMARKT

VAN MEDICI, JURISTEN EN ECONOMEN

2.1. Sexediscrepanties in de uitstroom uit het WO, in participatie, werkloosheid en deeltijdwerk

2.1.1. Uitstroom uit het WO 4

2.1.2. Participatiegraad 5

2.1.3. Werkloosheid 6

2.1.4. Deeltijdwerk 1

2.2. Sexediscrepanties in de beroepsuitoefening 8

2.2.1. Beroepssegregatie 9

2.2.2. Beroepsklasse- en branchespreiding 10

2.2.3. Onderbenutting en gemiddeld beroepsniveau 11

2.3. Sexediscrepanties in arbeidsmarktperspectief 12

3. SEXEDISCREPANTIES OP DE ARBEIDSMARKT VAN

AAN DE RL AFGESTUDEERDE MEDICI, GEZONDHEIDS-

WETENSCHAPPERS EN JURISTEN

3.1. Inleiding

3.2. Sexediscrepanties in onderwijsloopbaan

en werkervaring vóór afstuderen

3.3. Sexediscrepanties in arbeidsmarktintrede en $\begin{array}{ll}\text { huidige arbeidsmarktpositie } & 17\end{array}$

3.4. Sexediscrepantie in beroepsuitoefening 19

$\begin{array}{ll}\text { 3.4.1. Baanstabiliteit } & 19\end{array}$

3.4.2. Werkorganisaties 21

3.4.3. Beroep en branche 22

3.4.4. Functieniveau 23

3.4.5. Aansluiting onderwijs en functie 24

3.5. Sexediscrepanties in mobiliteit 26 
3.6. De betekenis van de factor sexe in de verklaring van de verschillen in arbeidsmarktpositie van afgestudeerden

4. CONCLUSIES

LITERATUUR

BIJLAGE I TABELLEN

BIJLAGE II DEFINITIE VAN ENDOGENEN EN EXOGENEN IN DE MULTIVARIATE ANALYSES

BIJLAGE III SCHATTINGSRESULTATEN VAN DE MULTIVARIATE ANALYSES 


\section{VERANTWOORDING}

Dit rapport vormt de neerslag van een studie naar sexe-ongelijkheid op de arbeidsmarkt van afgestudeerden van de Rijksuniversiteit Limburg. Het onderzoek is verricht door het Researchcentrum voor Onderwijs en Arbeidsmarkt met subsidie van het College van Bestuur van deze universiteit. Het doel van de studie is om informatie te verstrekken op basis waarvan het emancipatiebeleid van de Rijksuniversiteit Limburg meer gestalte zou kunnen krijgen.

Het onderzoek vond plaats onder leiding van dr. R.K.W. van der Velden en werd uitgevoerd door drs. B.J.H. Lodder, drs. P.J.E. van de Loo en drs. G.W.M. Ramaekers. 


\section{SAMENVATTING}

Met subsidie van het College van Bestuur van de Rijksuniversiteit Limburg (RL) heeft het Researchcentrum voor Onderwijs en Arbeidsmarkt (ROA) een onderzoek verricht naar sexeverschillen op de arbeidsmarkt van afgestudeerden van deze universiteit. Het onderzoek heeft als doel om te voorzien in de behoefte van de Vrouwen Emancipatie Commissie aan arbeidsmarktinformatie ten behoeve van haar emancipatiebeleid.

Gepoogd is om sexediscrepanties in de arbeidsmarktpositie van academici op twee niveaus zichtbaar te maken: eerst op landelijk niveau en vervolgens meer gedetailleerd op het niveau van de RL. Dit gebeurt aan de hand van een aantal arbeidsmarktgegevens dat betrekking heeft op de studierichtingen die aan de RL vertegenwoordigd zijn: geneeskunde, gezondheidswetenschappen, rechten en economie.

De landelijke gegevens over de arbeidsmarktpositie van academici hebben betrekking op de instroom op de arbeidsmarkt, de participatie aan het arbeidsproces, de uitgeoefende beroepen en de arbeidsmarktvooruitzichten van deze beroepen. Het aandeel van vrouwen in de uitstroom uit het WO neemt bij de nader beschouwde studierichtingen gestaag toe.

De arbeidsmarktparticipatie is bij vrouwen geringer dan bij mannen. Verder is geconstateerd dat vrouwen (geneeskundigen uitgezonderd) vaker werkloos zijn dan mannen. Ook werken vrouwen vaker in deeltijd. Vrouwen zijn doorgaans in een geringer aantal beroepen geconcentreeerd dan mannen. Bovendien komen vrouwen vaker in beroepsklassen met slechte arbeidsmarktperspectieven terecht. Sexeverschillen in spreiding over branches zijn gering.

Middels bivariate analyses is beschreven in hoeverre vrouwelijke en mannelijke afgestudeerden van de RL verschillen in hun onderwijs- en beroepsloopbaan. Verschillen zijn geconstateerd in de onderwijsloopbaan en de studiekeuze aan de RL. Met betrekking tot arbeidsmarktrelevante ervaring vóór afstuderen is alleen een verschil in betaalde werkervaring geconstateerd. Ten aanzien van de arbeidsmarktintrede en huidige maatschappelijke positie zijn geen sexeverschillen geconstateerd. Vrouwen blijken echter wel vaker in deeltijd te werken en een lager inkomen te verwerven. Verder blijkt dat vrouwen minder vaak in leidinggevende functies werkzaam zijn dan mannen. Met behulp van multivariate analyses is onderzocht in hoeverre het geslacht een verklarende factor vormt voor de geconstateerde verschillen. De onderzochte dimensies van de arbeidsmarktpositie van RL-afgestudeerden hebben betrekking op het al dan niet verrichten van betaalde arbeid, een aantal functiekenmerken en op baanmobiliteit. Bij de functiekenmerken gaat het om twee indicatoren voor de stabiliteit van de baan (baanzekerheid 
en werktijdfactor), drie indicatoren voor het niveau van de functie (inkomen, leidinggeven en vereist opleidingsniveau) en het volgen van aanvullend onderwijs. Gepoogd is om deze variabelen achtereenvolgens te verklaren met behulp van een aantal achtergrondkenmerken (geslacht, leeftijd, arbeidsmarktrelevante ervaring vóór afstuderen, gevolgde studierichting en aantal jaren arbeidsmarktervaring na afstuderen) en waar relevant vier baankenmerken (baanstabiliteit, functieniveau, aansluiting onderwijs en functie en 'on the job' leren). In de analyses kwam naar voren dat het geslacht bij de verklaring van de meeste dimensies van de arbeidsmarktpositie van pas afgestudeerde academici geen significante rol speelt. Alleen bij het werken in deeltijd, het inkomen en bij leidinggeven blijkt het geslacht een zelfstandig effect te hebben: vrouwen werken vaker in deeltijd, het inkomen is lager en zij geven minder vaak leiding.

Bij de geconstateerde sexeverschillen kan zelfselectie en discriminatie van vrouwen op de arbeidsmarkt een rol spelen. Het is aannemelijk dat vrouwen er bewust voor kiezen om in deeltijd te werken. Er is immers niet gebleken dat vrouwen vaker dan mannen werkloos zijn en daardoor gedwongen zijn om hun toevlucht te nemen tot dat segment van de arbeidsmarkt waar niet-leidinggevende, slecht betaalde deeltijdbanen te vergeven zijn. Bij de constatering dat vrouwen minder vaak in leidinggevende functies terechtkomen kan zelfselectie maar ook discriminatie een rol spelen. Het geconstateerde verschil in inkomen wijst in de richting van discriminatie. Immers in de analyse van het inkomen, dat gemeten is bij een volledige werkweek, is gecorrigeerd voor het feit dat mannen vaker een leidinggevende functie uitoefenen. 


\section{INLEIDING}

In het werkplan (1990-1992) van de Vrouwen Emancipatie Commissie (VEC) van de Rijksuniversiteit Limburg ( $R L)$ kan men lezen dat de VEC als uitgangspunt voor het emancipatiebeleid hanteert: "Het binnen de doelstellingen van de universiteit, scheppen van voorwaarden voor en het bevorderen van ontwikkelingen gericht op het bereiken van een situatie waar mannen en vrouwen gelijke rechten, kansen en vrijheden kunnen realiseren".

Met name op het gebied van arbeid blijkt dat de maatschappelijke norm van gelijkwaardigheid tussen de sexen in de praktijk niet automatisch wordt gerealiseerd. Voor het emancipatiebeleid van de VEC is het daarom van belang om te beschikken over een aantal kerngegevens die een indicatie verschaffen met betrekking tot de actuele sexe-ongelijkheid op de arbeidsmarkt.

Alvorens in te gaan op het doel en de inhoud van dit onderzoek, wordt aangegeven welke vormen van sexe-ongelijkheid te vinden zijn op de arbeidsmarkt volgens de literatuur op dit terrein. Bruyn-Hundt (1988) noemt een aantal kernpunten ten aanzien van de sexe-ongelijkheid op de arbeidsmarkt: "vrouwen ontbreken op de arbeidsmarkt omdat er kleine kinderen verzorgd moeten worden; zij werken vaker in deeltijd; de opleiding van vrouwen is minder beroepsgericht; vrouwen werken in 'vrouwenberoepen', waardoor zij geconcentreerd zijn in een geringer aantal beroepen en sectoren dan mannen; in hogere functieniveaus ontbreken vrouwen nagenoeg geheel; de werkloosheid onder vrouwen is hoger dan die onder mannen, vooral als rekening wordt gehouden met de 'verborgen' werkloosheid; vrouwen hebben een lager uurloon dan mannen; een deel van dit verschil kan niet door objectieve factoren zoals leeftijd, opleiding e.d. verklaard worden, maar moet worden toegeschreven aan discriminatie."

Bovenstaande constateringen hebben betrekking op de arbeidsmarkt als geheel. In hoeverre deze ook van toepassing zijn op dat deel van de arbeidsmarkt waar afgestudeerden van de $R L$ actief zijn is op voorhand niet duidelijk. Dit onderzoek poogt inzicht te verschaffen in deze problematiek.

Dit rapport heeft als doel om te voorzien in de behoefte van de VEC aan arbeidsmarktinformatie ten behoeve van het emancipatiebeleid van de RL. Dit rapport kan tevens worden beschouwd als een eerste aanzet tot het permanent genereren van sexespecifieke informatie uit het ROAonderzoeksproject 'Arbeidsmarktscanner Rijksuniversiteit Limburg'.

De sexediscrepanties worden in dit rapport beschreven op twee niveau's; eerst op landelijk niveau en vervolgens op het niveau van één universiteit, de RL. Dit gebeurt aan de hand van 
een aantal arbeidsmarktgegevens dat betrekking heeft op de studierichtingen die aan de RL vertegenwoordigd zijn: geneeskunde, gezondheidswetenschappen, rechten en economie. Bij landelijke cijfers gaat het in de meeste gevallen om de totale beroepsbevolking (ontleend aan de $\mathrm{AKT}$ ); bij de cijfers van de $\mathrm{RL}$ gaat het om pas afgestudeerden.

De landelijke gegevens zijn deels ontleend aan het 'Informatiesysteem Onderwijs-Arbeidsmarkt' dat door het ROA in opdracht van het Ministerie van Onderwijs en Wetenschappen is ontwikkeld. Deels zijn aanvullende gegevens verzameld bij het CBS. Aangezien de bestaande gegevens tekort schieten om een beeld te geven van de landelijke arbeidsmarktsituatie bij gezondheidswetenschappen, beperkt de landelijke informatie zich tot de overige drie studierichtingen, namelijk geneeskunde, rechtsgeleerdheid en economie. Het betreft informatie over de sexe-verschillen in:

- de uitstroom van deze opleidingen naar de arbeidsmarkt en de verwachte ontwikkeling hierin;

- arbeidsmarktparticipatie, werkloosheid en deeltijdwerk;

- beroepsuitoefening;

- arbeidsmarktvooruitzichten.

Vervolgens wordt de arbeidsmarktpositie van mannelijke en vrouwelijke afgestudeerden van de $\mathrm{RL}$ geschetst. Op basis van het databestand, dat gegenereerd is door de 'Arbeidsmarktscanner $\mathrm{RL}^{\prime}$, worden sexe-verschillen onderzocht in:

- relevante arbeidsmarktervaring vóór afstuderen;

- arbeidsmarktintrede en huidige arbeidsmarktsituatie;

- beroepsuitoefening;

- arbeidsmobiliteit.

Gezien het nog geringe aantal (vrouwelijke) economen in het databestand is het niet verantwoord om uitspraken te doen over sexeverschillen met betrekking tot afgestudeerden van de Faculteit der Economische Wetenschappen. Om deze reden beperkt de RL-informatie zich tot de overige drie studierichtingen, namelijk geneeskunde, gezondheidswetenschappen en Nederlands recht.

Middels bivariate analyses wordt onderzocht in hoeverre vrouwen en mannen verschillend scoren op bovengenoemde dimensies van de arbeidsmarktpositie. Vervolgens wordt met behulp van multivariate analyses onderzocht in hoeverre sexe kan worden beschouwd als een verklarende factor voor de variatie in de scores op de diverse dimensies van de arbeidsmarktpositie van afgestudeerden van de RL. 
$-3-$

De landelijke gegevens zullen - waar mogelijk - worden vergeleken met de arbeidsmarktpositie van RL-afgestudeerden en de daarbinnen optredende sexe-verschillen.

De opbouw van dit rapport is als volgt. In hoofdstuk 2 wordt een beeld geschetst van de landelijke situatie. De paragraaf-indeling komt overeen met bovengenoemde aspecten van de sexe-verschillen op de arbeidsmarkt. In hoofdstuk 3 wordt ingegaan op de sexe-verschillen met betrekking tot de afgestudeerden van de RL. De indeling der paragrafen correspondeert eveneens met bovengenoemde aspecten van de sexe-verschillen in arbeidsmarktpositie. In hoofdstuk 4 worden de landelijke gegevens vergeleken met de gegevens van de RL. Tevens wordt in dit hoofstuk een aantal conclusies getrokken en aanbevelingen geformuleerd. 


\section{SEXEDISCREPANTIES OP DE LANDELIJKE ARBEIDSMARKT VAN MEDICI, JURISTEN EN ECONOMEN}

\subsection{Sexediscrepanties in de uitstroom uit het WO, in participatie, werkloosheid en deeltijdwerk}

In dit hoofdstuk wordt een aantal landelijke kerncijfers gepresenteerd met betrekking tot de sexe-verschillen in de arbeidsmarktpositie van medici, juristen en economen. De bestaande gegevens maken het niet goed mogelijk om een beeld te geven van de landelijke arbeidsmarktsituatie bij gezondheidswetenschappen. Data betreffende deze betrekkelijk jonge studie zijn nog in onvoldoende mate aanwezig (Van Dam, Heijke en Ramaekers, 1989).

Allereerst zullen de sexe-discrepanties in de uitstroom uit het WO, in arbeidsmarktparticipatie, werkloosheid en deeltijdwerk worden behandeld. Vervolgens worden de sexe-discrepanties in de beroepsuitoefening besproken. Als laatste komen de verschillen in arbeidsmarktperspectief voor mannen en vrouwen aan bod.

\subsubsection{Uitstroom uit het wO}

In tabel I van bijlage I wordt de landelijke uitstroom uit het WO van afgestudeerde geneeskundigen, gezondheidswetenschappers, juristen en economen naar sexe weergegeven. Ter vergelijking zijn de cijfers van de $\mathrm{RL}$ toegevoegd.

Uit de tabel is, wat betreft de landelijke uitstroom, op te maken dat bij geneeskunde en rechten het percentage vrouwen gestaag is toegenomen. Bij gezondheidswetenschappen is het percentage vrouwen tamelijk stabiel, maar wel hoog (rond 70\%). Het percentage vrouwen bij economie is eveneens sterk gestegen, hoewel het percentage laag blijft. Met betrekking tot de toekomst, wordt verwacht dat de huidige trends kunnen worden doorgetrokken. Bij geneeskunde en rechten zal er een langzame stabiele groei van vrouwelijke afgestudeerden optreden. Bij gezondheidswetenschappen blijft het aandeel van vrouwen stabiel. Bij economie is sprake van een behoorlijke groei. In het jaar 2000 zal het percentage vrouwen in deze studierichting ongeveer $25 \%$ bedragen.

De percentages vrouwen bij de RL liggen doorgaans iets hoger dan de landelijke percentages. Het gaat echter om een nog gering aantal waarnemingen in de tijd en het is daarom nog te vroeg om de verschillen tussen landelijke en RL-percentages als structureel te beschouwen. 


\subsubsection{Participatiegraad}

De participatiegraad, gedefinieerd als het procentuele aandeel van de beroepsbevolking in de totale bevolking, verschilt tussen mannen en vrouwen. De participatiegraad van vrouwen met een voltooide universitaire opleiding is licht toegenomen van $84.1 \%$ in 1981 naar $85.9 \%$ in 1990, terwijl die van mannen is gedaald. Als gevolg hiervan is het procentuele verschil tussen de participatiegraad van mannen en vrouwen met een universitaire opleiding afgenomen van $16,6 \%((98.1-84.1) / 84.1 * 100 \%)$ in 1981 tot $9.9 \%$ in 1990 . In tabel 1 worden de participatiegraden van mannen en vrouwen in 1981 en 1990 per opleidingsrichting weergegeven. Hierin komt naar voren dat voor de economische en juridische studierichtingen de 'voorsprong' van mannen in de jaren tachtig duidelijk is afgenomen. Voor de medische studierichtingen (geneeskunde en gezondheidswetenschappen) is het procentuele verschil tussen mannen en vrouwen toegenomen. In tegenstelling tot de overige studierichtingen daalt de participatiegraad van vrouwen met een medische achtergrond. Voor de mannen is de participatiegraad bij alle studierichtingen gedaald.

Tabel 1. Participatiegraad van academici naar sexe en opleidingrichting in 1981 en 1990

\begin{tabular}{lllllll}
\hline & \multicolumn{2}{c}{1981} & & \multicolumn{2}{c}{1990} & \multicolumn{2}{c}{$\begin{array}{l}\text { procentueel } \\
\text { verschil }\end{array}$} \\
& man & vrouw & verschil & man & vrouw & \\
\hline Medisch & 97.8 & 86.1 & 13.6 & 91.1 & 75 & 21.5 \\
Economisch & 98.2 & 66.7 & 47.2 & 95.8 & 80 & 19.8 \\
Jur/Best* & 98.4 & 75.9 & 29.6 & 94.9 & 87.9 & 7.9 \\
WO-totaal & 98.1 & 84.1 & 16.6 & 94.4 & 85.9 & 9.9 \\
\hline
\end{tabular}

Bron: CBS, ROA

Het is mogelijk om voor 1981 een beeld te geven van de leeftijdsopbouw van de participatiegraad. In tabel 2 wordt de participatiegraad per leeftijdscategorie voor mannen en vrouwen weergegeven. In de laatste twee kolommen wordt voor mannen en vrouwen apart het procentuele verschil ten opzichte van het (gewogen) gemiddelde van alle leeftijdscategrorieën weergegeven. Zo is bijvoorbeeld de participatiegraad van vrouwen tussen $20-24$ jaar $7 \%$ hoger dan van vrouwen tussen 15-65 jaar. Uit deze laatste kolommen blijkt dat in de leeftijdscategorie 20-29 jaar vrouwen relatief veel participeren, en mannen relatief weinig. Het gegeven dat vrouwen niet in militaire dienst hoeven kan hierbij een rol spelen. Voor mannen en vrouwen ouder dan 54 is de participatiegraad relatief gering. Dit geldt in sterkere mate voor vrouwen dan voor mannen. Vrouwen trekken zich op jongere leeftijd terug uit het arbeidsproces dan mannen. 
$-6-$

Tabel 2. Participatiegraad van academici naar sexe en leeftijd in 1981

\begin{tabular}{lcccc}
\hline & \multicolumn{2}{c}{$\begin{array}{c}\text { Participatiegraad } \\
\text { man }\end{array}$} & vrouw & \multicolumn{2}{c}{$\begin{array}{c}\text { Procentueel verschil } \\
\text { man }\end{array}$} & vrouw \\
\hline leeftijdscategorie & & & & 7 \\
$20-24$ & 93.3 & 90 & -4.9 & 8.8 \\
$25-29$ & 99.2 & 91.5 & 1.1 & 3.4 \\
$30-34$ & 99.5 & 87 & 1.4 & 1.1 \\
$35-39$ & 99.7 & 85 & 1.6 & 1.4 \\
$40-44$ & 100 & 85.3 & 1.9 & -2.7 \\
$45-49$ & 98.7 & 81.8 & -0.1 & -1.9 \\
$50-54$ & 98 & 85.7 & -2.4 & -74.6 \\
$55-59$ & 95.7 & 71.4 & -17.9 & 0 \\
$60-64$ & 80.5 & 21.4 & & 0 \\
\end{tabular}

Bron: CBS

\subsubsection{Werkloosheid}

Op basis het Bemiddelingsbestand Zonder Baan van het Ministerie van Sociale Zaken en Werkgelegenheid enerzijds en gegevens over de uitstroom uit het onderwijs anderzijds, is het mogelijk het aandeel van werkloze schoolverlaters te berekenen als percentage van het totaal aantal schoolverlaters.

In tabel 3 wordt het totaal antal werkloze schoolverlaters per WO-opleidingsrichting voor de periode 1986-1989 weergegeven. Het aandeel van vrouwen wordt eveneens vermeld. In tabel 3 komt naar voren dat het aantal werklozen een stijgende trend vertoont. Deze stijging kan verband houden met de instroom van WO-opgeleiden op de arbeidsmarkt die juist in deze periode versneld optrad als gevolg van de gelijktijdige uitstroom uit het WO van de laatste generaties 'oude-stijl studenten' en de eerste generaties 'eerste fase studenten'. Het aandeel van vrouwen in de werkloosheid is bij de drie onderscheiden opleidingsrichtingen lager dan bij het wetenschappelijk onderwijs als geheel.

Tabel 3. Absolute aantallen werkloze academische schoolverlaters en het percentage vrouwen, 1986-1989

\begin{tabular}{lcccccccr}
\hline & $\begin{array}{l}1986 \\
\text { VROUW } \\
\%\end{array}$ & $\begin{array}{l}1986 \\
\text { TOTAALIDING } \\
\text { (abs.) }\end{array}$ & $\begin{array}{l}1987 \\
\text { VROUW } \\
\%\end{array}$ & $\begin{array}{l}1987 \\
\text { TOTAAL } \\
\text { (abs.) }\end{array}$ & $\begin{array}{l}1988 \\
\text { VROUW } \\
\%\end{array}$ & $\begin{array}{l}1988 \\
\text { TOTAAL } \\
\text { (abs.) }\end{array}$ & $\begin{array}{l}1989 \\
\text { VROUW } \\
\%\end{array}$ & $\begin{array}{l}1989 \\
\text { TOTAAL } \\
\text { (abs.) }\end{array}$ \\
\hline Econ.ws & 9.1 & 208 & 10.3 & 243 & 15.4 & 436 & 17.3 & 502 \\
Jr/Bst.ws & 33.6 & 864 & 38.2 & 872 & 39.9 & 1225 & 40.8 & 1506 \\
(P)Med.ws & 30.4 & 1085 & 36.3 & 1077 & 37.8 & 1121 & 41.3 & 1034 \\
WO-tot & 38.7 & 7882 & 41.2 & 7904 & 41.6 & 10625 & 43 & 11810 \\
\hline
\end{tabular}

Bron: Ministerie van Sociale Zaken en Werkgelegenheid, Bemiddelingsbestand Zonder Baan 
$-7-$

Een goede werkloosheidsindicator is het aantal werkloze schoolverlaters als percentage van het totaal aantal schoolverlaters. In tabel 4 wordt dit percentage voor respectievelijk mannen, vrouwen en mannen en vrouwen samen weergegeven. Er is geen stijgende of dalende trend waarneembaar in deze percentages. Wel blijkt het werkloosheidspercentage in de onderscheiden studierichtingen lager te zijn dan in het wetenschappelijk onderwijs als geheel.

Tabel 4. Werkloze academische schoolverlaters als percentage van de uitstroom uit het WO

\begin{tabular}{lllllll}
\hline & 1986 & $\begin{array}{l}1986 \\
\text { VROUW }\end{array}$ & $\begin{array}{l}1986 \\
\text { TOTAAL }\end{array}$ & $\begin{array}{l}1987 \\
\text { MAN }\end{array}$ & $\begin{array}{l}1987 \\
\text { VROUW }\end{array}$ & $\begin{array}{c}1987 \\
\text { TOTAAL }\end{array}$ \\
\hline ECON. & 14.25 & 15.97 & 14.39 & 13.28 & 12.76 & 13.22 \\
JUR/BEST & 31.21 & 28.43 & 30.22 & 27.53 & 28.08 & 27.74 \\
GENEESK. & 38.76 & 28.18 & 34.79 & 35.94 & 30.55 & 33.77 \\
WO-tot & 40.92 & 50.61 & 44.2 & 34.59 & 44.1 & 37.96 \\
\hline
\end{tabular}

\begin{tabular}{lllllll}
\hline OPLEIDING & $\begin{array}{l}1988 \\
\text { MAN }\end{array}$ & $\begin{array}{l}1988 \\
\text { VROUW }\end{array}$ & $\begin{array}{l}1988 \\
\text { TOTAAL }\end{array}$ & $\begin{array}{l}1989 \\
\text { MAN }\end{array}$ & $\begin{array}{l}1989 \\
\text { VROUW }\end{array}$ & $\begin{array}{c}1989 \\
\text { TOTAAL }\end{array}$ \\
\hline ECON. & 17.75 & 25.38 & 18.61 & 19.65 & 23.77 & 20.26 \\
JUR/BEST & 30.3 & 29.42 & 29.94 & 41.92 & 40.24 & 41.22 \\
GENEESK. & 47.13 & 36.81 & 42.61 & 47.83 & 37.36 & 42.87 \\
WO-tot & 33.52 & 40.65 & 36.16 & 44.42 & 52.87 & 47.7 \\
\hline
\end{tabular}

Bron: ROA, WORSA

In tabel 5 wordt de verhouding tussen het werkloosheidspercentage van vrouwen en het precentage van mannen weergegeven. Indien de verhouding groter is dan 1 houdt dit in dat vrouwen relatief meer werkloos zijn dan mannen. Naar voren komt dat vrouwelijke schoolverlaters bij de onderscheiden studierichtingen relatief weinig werkloosheid kennen in vergelijking met de schoolverlaters van het wetenschappelijk onderwijs als geheel. Bovendien is het werkoosheidspercentage voor vrouwen gemiddeld lager dan het percentage voor de mannen, tenminste wat de studierichtingen rechten/bestuurskunde en geneeskunde betreft. 
Tabel 5. Verhouding tussen werkloosheidsaandelen van mannelijke en vrouwelijke academische schoolverlaters

\begin{tabular}{llllll}
\hline Opleiding & 1986 & 1987 & 1988 & 1989 & GEM \\
\hline ECON. & 1.12 & 0.96 & 1.43 & 1.21 & 1.18 \\
JUR/BEST & 0.91 & 1.02 & 0.97 & 0.96 & 0.97 \\
GENEESK. & 0.73 & 0.85 & 0.78 & 0.78 & 0.79 \\
WO-tot & 1.24 & 1.27 & 1.21 & 1.19 & 1.23 \\
\hline
\end{tabular}

Bron: ROA

\subsubsection{Deeltijdwerk}

De sexe-verdeling met betrekking tot het al dan niet in deeltijd werken wordt naar gevolgde WO-studierichting weergegeven in tabel II van bijlage I. Onder deeltijdwerk wordt verstaan: een werkweek korter dan 30 uur.

In 1979 bestaat ongeveer $30 \%$ van de economen uit vrouwen. Bijna $12 \%$ van alle economen werkt in deeltijd. Bij de vrouwen is het percentage deeltijdwerkers beduidend hoger: $31 \%$. De chi-kwadraat toets geeft aan dat vrouwen, met een economie opleiding als achtergrond, significant meer in deeltijd werken dan mannen, met een economie opleiding als achtergrond. Ten opzichte van de totale steekproef is $30 \% * 30 \%=9 \%$ vrouwen werkzaam in deeltijd. Tussen 1979 en 1985 is het aantal vrouwelijke economen - procentueel gezien - nauwelijks toegenomen. Het percentage vrouwen dat parttime werkt is aanzienlijk gestegen (van $31,5 \%$ naar $38,5 \%$ ). Op basis van een chi-kwadraat toets (chi-kwadraat $=78,0 ; \mathrm{df}=1$ ) $k$ an worden geconstateerd dat de verschillen in de percentages tussen 1979 en 1985 significant zijn.

Het beeld voor de werkenden met een geneeskunde opleiding is vrijwel identiek aan het beeld voor de economen. Vrouwen werken significant meer in deeltijd, en de verschillen tussen 1979 en 1985 zijn eveneens significant. Voor de werkenden met een rechten-studie als achtergrond is het beeld eveneens globaal hetzelfde. Alleen het percentage vrouwen en deeltijdwerkers is hoger.

\subsection{Sexediscrepanties in de beroepsuitoefening}

De mate waarin sexediscrepanties bestaan in de beroepsuitoefening wordt aan de hand van een aantal kengetallen weergegeven. Ten eerste worden aan de hand van de verdeling over de beroepen per opleiding twee segregatieindices berekend. Ten tweede zullen voor vrouwen en 
$-9-$

mannen afzonderlijk indicatoren voor de beroepsklasse- en branchespreiding worden berekend. Vervolgens worden cijfers gepresenteerd over de mate van onderbenutting en het gemiddelde beroepsniveau.

\subsubsection{Beroepssegregatie}

In tabel III van bijlage I worden de belangrijkste beroepsklassen per opleidingstype naar sexe vermeld. De beroepsklassen zijn gemeten op 2-digit niveau volgens de beroepenclassificatie die door het CBS wordt gehanteerd. De percentages per opleidingstype tellen voor mannen en vrouwen tot $100 \mathrm{op}$, zodat gecorrigeerd is voor het feit dat er (absoluut) meer mannen dan vrouwen werkzaam zijn.

Bij de studierichting geneeskunde is het merendeel werkzaam als geneeskundige/verpleger(ster). Met betrekking tot de uitgeoefende beroepen zijn de verschillen tussen mannen en vrouwen gering.

Bij economie is sprake van een duidelijk grotere spreiding over verschillende beroepsklassen. Er doen zich behoorlijke verschillen tussen mannen en vrouwen voor. Vrouwen zijn relatief vaker werkzaam in de volgende beroepsklassen:

- hogere en middelbare technici en bedrijfskundigen;

- boekhouders;

- docenten.

Mannen zijn relatief vaak werkzaam in de volgende beroepsklassen:

- economen;

- accountants;

- hoger leidinggevend personeel.

Bij de studierichting rechten werkt ongeveer de helft van de mannen als jurist. Het percentage juristen bij vrouwen is $60 \%$. Verder werken vrouwen vaker als docent, terwijl mannen vaker hogere leidinggevende posities bekleden.

Goede maatstaven om de verschillen tussen de beroepsklassenspreiding van mannen en vrouwen weer te geven zijn de segregatieindex (s) en de gecorrigeerde segregatieindex (S). De index (s) bij geneeskunde geeft het antwoord op de vraag hoe groot de som is van het percentage van de mannelijke oud-geneeskunde studenten en het percentage van de vrouwelijke oud-geneeskunde studenten dat van beroepsklasse dient te veranderen ten einde segregatie te doen verdwijnen. De gecorrigeerde index (S) geeft aan welk percentage van alle oud- 
geneeskunde studenten van beroepsklasse moet veranderen, onder de restrictie dat de verdeling van het totaal aantal oud-geneeskunde studenten over de verschillende beroepsklassen ongewijzigd blijft. Voor de studierichtingen rechten en economie is de betekenis van de indices analoog ${ }^{1}$.

Tabel 6. Segregatie-indices per WO-opleidingsrichting

\begin{tabular}{lcl}
\hline Opleidingsrichting & $\mathrm{s}$ & $\mathrm{s}$ \\
\hline Geneeskunde & 4.87 & 1.66 \\
Rechten & 29.8 & 9.9 \\
Economie & 56.4 & 5.45 \\
\hline
\end{tabular}

In tabel 6 blijkt dat de segregatie-index s per opleidingsrichting sterk verschilt. De sexeverschillen ten aanzien van de uitgeoefende beroepsklassen zijn bij geneeskunde het kleinst en bij rechten het grootst. De 'scheve' man/vrouw-verhouding bij economie (95/5) leidt er toe dat de gecorrigeerde index $\mathrm{S}$ voor economie gering is in vergelijking tot $\mathrm{s}$.

\subsubsection{Beroepsklasse- en branchespreiding}

De Gini-Hirschman coëfficient is een maatstaf die een indicatie geeft van de bestaande flexibiliteit op de arbeidsmarkt, dit wel zeggen van de uitwijkmogelijkheden naar andere beroepen en branches die een bepaalde opleiding biedt. Op basis van deze maatstaf kunnen de de branche- en beroepsklassenspreiding worden bepaald. De indicator neemt waarden aan tussen 0 en 1 . De beroepsklassenspreiding per opleidingstype is 0 als de opleidingsrichting slechts in één beroepsklasse voorkomt en 1 als de opleidingsrichting gelijkmatig over alle beroepen is verspreid.

Zowel bij rechten als economie blijkt de beroepsklassenspreiding bij mannen hoger te zijn dan bij vrouwen. Dit wil zeggen dat mannelijke afgestudeerden van deze opleidingsrichtingen in een groter aantal beroepen terecht komen dan vrouwen. Wel neemt het aantal beroepen waarin vrouwelijke economen terecht komen toe. Bij geneeskunde is het verschil in spreiding over beroepen tussen mannen en vrouwen gering.

1. Een uitvoerige analyse voor de gehele beroepsbevolking is te vinden in ROA (1991). De formules voor de indices zijn te vinden in Siegers (1979). 
Tabel 7. Branche- en beroepsklassenspreiding: per WO-studierichting (Gini-Hirschman coëfficient)

\begin{tabular}{|c|c|c|c|c|}
\hline & \multicolumn{2}{|c|}{ vrouwen } & \multicolumn{2}{|c|}{ mannen } \\
\hline & 79 & $' 85$ & 79 & $' 85$ \\
\hline \multicolumn{5}{|c|}{ Beroepsklassenspreiding } \\
\hline Geneeskunde & 0.235 & 0.251 & 0.249 & 0.248 \\
\hline Rechten & 0.666 & 0.611 & 0.706 & 0.729 \\
\hline Economie & 0.608 & 0.818 & 0.846 & 0.861 \\
\hline \multicolumn{5}{|c|}{ Branchespreiding } \\
\hline Geneeskunde & 0.088 & 0.329 & 0.186 & 0.324 \\
\hline Rechten & 0.813 & 0.784 & 0.753 & 0.806 \\
\hline Economie & 0.830 & 0.881 & 0.996 & 0.900 \\
\hline
\end{tabular}

Wat de branche-spreiding betreft kan worden opgemerkt dat deze voor economen bij mannen hoger was dan bij vrouwen. Het verschil neemt echter af. Bij geneeskunde zien we dat zowel mannen als vrouwen in een toenemend aantal bedrijfssectoren terecht komen.

\subsubsection{Onderbenutting en gemiddeld beroepsniveau}

Indien vrouwen en mannen werkzaam zijn op een beroepsniveau dat lager ligt dan hun opleidingsniveau is er sprake van onderbenutting. In tabel 8 wordt het percentage dat werkzaam is op een lager beroepsniveau dan waarvoor men gekwalificeerd is per opleidingsrichting en geslacht weergegeven. Daarnaast kan het gemiddelde beroepsniveau, waarbij de niveau's kunnen varieren tussen 1 (ongeschoold) en 7 (wetenschappelijke specialisten e.d.), per opleidingsrichting en geslacht worden berekend. Dit wordt eveneneens in tabel 8 weergegeven. Bij de berekening van het gemiddelde beroepsniveau is gebruik gemaakt van de niveaus die door Huijgen (1989) aan de beroepen (volgens CBS-beroepenclassificatie op 3-digitniveau) zijn toegekend.

In tabel 8 komt naar voren dat met name bij vrouwelijke economen een bijzonder hoge mate van onderbenutting bestaat. Maar liefst $56 \%$ van deze economen werkt onder haar niveau. Ook is opvallend dat bij geneeskunde - in tegenstelling tot rechten en economie - de onderbenutting bij vrouwen kleiner is dan bij mannen. 
Tabel 8. Onderbenutting en gemiddeld beroepsniveau per opleidingsrichting in 1985

\begin{tabular}{|c|c|c|c|c|c|}
\hline \multirow[t]{2}{*}{ Opleidingsrichting } & \multicolumn{3}{|c|}{$\%$ Onderbenutting } & \multicolumn{2}{|c|}{ Gemiddeld beroepsniveau } \\
\hline & vrouwen & mannen & totaal & vrouwen & mannen \\
\hline Geneeskunde & 2.76 & 4.63 & 4.23 & 6.9 & 6.8 \\
\hline Rechten & 18.72 & 13.95 & 14.95 & 6.2 & 6.2 \\
\hline Economie & 56.00 & 13.28 & 15.45 & 5.3 & 5.9 \\
\hline
\end{tabular}

Wat het gemiddelde beroepsniveau betreft is alleen bij economie een duidelijk verschil tussen mannen en vrouwen aanwezig.

\subsection{Sexediscrepanties in arbeidsmarktperspectief}

In de rapportage 'De arbeidsmarkt naar opleiding en beroep tot 1994' van het ROA (1991) worden arbeidsmarktperspectieven voor elke opleidingsrichting - dus ook voor geneeskunde, rechten en economie - weergegeven. Deze arbeidsmarktperspectieven gelden voor de opleiding als geheel. In deze paragraaf wordt nagegaan in hoeverre vrouwen met een opleiding geneeskunde, economie of rechten een verschillend arbeidsmarktperspectief hebben dan mannen. Sexediscrepanties kunnen ontstaan door verschillen in arbeidsmarktperspectief voor beroepen waarin met name vrouwen respectievelijk mannen werkzaam zijn. Zo betekent een grote uitbreidingsvraag in een beroepsklasse waarin relatief veel vrouwen werkzaam zijn dat de werkgelegenheid voor vrouwen relatief (ten opzichten van mannen) toeneemt.

Bij deze benadering moet de kanttekening worden gemaakt dat moet worden verondersteld dat de sexeverdeling over de beroepen constant is in de tijd.

In tabel 9 wordt het verschil tussen de gemiddelde uitbreidingsvraag lover relevante beroepsklassen) per opleidingsrichting voor vrouwen en mannen weergegeven. Daarbij is de uitbreidingsvraag voor vrouwen en mannen uitgedrukt als percentage van het aantal reeds werkende vrouwen en mannen. Dit houdt in dat een identiek percentage voor vrouwen en mannen niet betekent dat er absoluut evenveel mannen als vrouwen extra aan het werk kunnen.

Uit de tabel blijkt dat er sprake is van een ontwikkeling waarin vrouwen minder profiteren van de totale uitbreidingsvraag omdat zij terecht komen in beroepsklassen waarin de uitbreidingsvraag relatief - ten opzichte van andere relevante beroepsklassen behorende bij de opleidingsrichting - gering is. 
$-13-$

Tabel 9. Gemiddelde uitbreidingsvraag per opleidingsrichting naar sexe t.o.v. het aantal werkenden naar sexe

\begin{tabular}{lcc} 
Opleidingsrichting & Vitbreidingsvraag in \% & Mannen \\
\hline & Vrouwen & 6.8 \\
Geneeskunde & 6.6 & 4.6 \\
Rechten & 3.5 & 8.9 \\
Economie & 5.3 & \\
\hline
\end{tabular}


$-14-$

\section{SEXEDISCREPANTIES OP DE ARBEIDSMARKT VAN AAN DE RL AFGESTUDEERDE MEDICI, GEZONDHEIDSWETENSCHAPPERS EN JURISTEN}

\subsection{Inleiding}

Op verzoek van het College van Bestuur van de RL heeft het Researchcentrum voor Onderwijs en Arbeidsmarkt een arbeidsmarktscanner voor afgestudeerden van deze universiteit ontwikkeld (Ramaekers en Heijke, 1991). Het hiermee gegenereerde databestand wordt ten behoeve van het onderhavige onderzoek gebruikt om uitspraken te doen over de sexediscrepanties op de arbeidsmarkt van oud-studenten die in de periode 1986-1989 aan de RL zijn afgestudeerd. De analyse van het bestand komt in grote lijnen overeen met de analyse van Ramaekers en Heijke. Het accent ligt echter meer op de sexediscrepanties en minder op de verschillen tussen faculteiten.

De arbeidsmarktscanner voor afgestudeerden kent de volgende opzet:

Alle oud-studenten worden circa één jaar na afstuderen met behulp van een basisvragenlijst benaderd. Vervolgens wordt hen jaarlijks een jaarkaart toegestuurd waarmee zij mutaties kunnen doorgeven. De jaarkaart is een verkorte versie van de basisvragenlijst. Bij de start van de dataverzameling in 1990 zijn de lichtingen 1986 tot en met 1988 integraal benaderd met een aangepaste basisvragenlijst waarbij de loopbaan retrospectief in kaart is gebracht. De lichting 1989 is in september 1990 met de reguliere vragenlijst benaderd. In het najaar van 1991 zullen deze vier lichtingen voor de eerste keer met de jaarkaart worden benaderd. Het uiteindelijke bestand dat gebruikt is voor de analyses ten behoeve van het onderhavige onderzoeksverslag heeft 1100 waarnemingen. Het aantal vrouwen in het bestand bedraagt 612 (ofwel $56 \%$ ).

$\mathrm{Er}$ is besloten om geen cijfers te presenteren betreffende de sexediscrepanties van afgestudeerden van de Faculteit der Economische Wetenschappen. Door het geringe aantal (vrouwelijke) economen in het databestand is het niet mogelijk om uitspraken te doen over sexeverschillen.

De opbouw van dit hoofdstuk is als volgt. In paragraaf 3.2. wordt ingegaan op de verschillen in opleiding tussen mannen en vrouwen. Het gaat hierbij om verschillen in vooropleiding, de keuze van de studie- en afstudeerrichting aan de RL en relevante werkervaring vóór afstuderen. In paragraaf 3.3. wordt gekeken naar sexediscrepanties bij de intrede op de arbeidsmarkt en naar de huidige maatschappelijke positie. In paragraaf 3.4. wordt een aantal dimensies besproken van de sexediscrepanties in beroepsuitoefening. Het betreft discrepanties in baanzekerheid, type 
werkorganisatie, beroep, functieniveau en de aansluiting tussen het genoten onderwijs en de huidige baan. Deze paragraaf heeft alleen betrekking op het deel van de respondenten dat thans (op het moment van bevraging) een betaalde baan heeft en op het deel van de thans niet betaald werkende retrospectief bevraagde oud-studenten dat na afstuderen betaald werk heeft gehad. De lezer wordt verwezen naar Ramaekers en Heijke (1991) voor een meer uitvoerige behandeling van de data. Sexediscrepanties in (potentiële) mobiliteit zijn het onderwerp van paragraaf 3.5 .

Op het bestand zijn twee soorten analyses verricht. Ten eerste zijn bivariate kruistabellen gemaakt waarbij onderzocht kan worden of een specifieke variabele (bijvoorbeeld opleidingseisen) significant verschillend is voor mannen en vrouwen. Vervolgens zijn multivariate analyses verricht om te onderzoeken of het weglaten van mogelijk intervenierende variabelen geen vertekend beeld geeft van de situatie. Omwille van de overzichtelijkheid worden de multivariate analyses voor alle aspecten tegelijk besproken in paragraaf 3.6.

\subsection{Sexediscrepanties in onderwijsloopbaan en werkervaring vóór afstuderen}

Onderzocht is in hoeverre er verschillen zijn tussen mannen en vrouwen met betrekking tot de vooropleiding en de keuze van de studie/afstudeerrichting aan de Rijksuniversiteit Limburg. Tabel 10 geeft een beeld van de sexeverschillen per faculteit met betrekking tot het al dan niet gevolgd hebben van VWO als hoogste voltooide vooropleiding.

Tabel 10. Percentage studenten met VWO als hoogste voltooide vooropleiding, per faculteit naar geslacht

\begin{tabular}{|c|c|c|c|c|}
\hline Faculteit & Vrouw & Man & Totaal & Chi-kwadraat \\
\hline FdG & 92 & 88 & 90 & 1.8 \\
\hline FdGW & 83 & 75 & 81 & 2.9 \\
\hline FdR & 87 & 79 & 83 & 3.5 \\
\hline $\mathrm{RL}$ & 81 & 86 & 84 & $4.9 *$ \\
\hline
\end{tabular}

\footnotetext{
* = significant op $5 \%$ niveau
}

Op basis van deze tabel kan worden geconcludeerd dat vrouwen relatief vaker uitsluitend een VWO opleiding hebben gevolgd. Mannen hebben dus vaker reeds een initiële opleiding voltooid waarop ze kunnen terugvallen bij de intrede op de arbeidsmarkt na verlaten van de RL. De verschillen zijn alleen significant voor het gehele bestand en niet voor de specifieke studierichtingen. 
$-16-$

Tabel 11 geeft een beeld van de gekozen studierichting aan de RL. Naar voren komt dat mannen significant vaker voor geneeskunde en rechten hebben gekozen, en vrouwen vaker voor gezondheidswetenschappen.

Tabel 11. Gevolgde studierichting aan de RL, naar geslacht (in \%)

\begin{tabular}{lrrr}
\hline Studierichting & Vrouw & Man & Totaal \\
\hline & 24 & 37 & 30 \\
Geneeskunde & 47 & 20 & 35 \\
Gezondheidswet. & 27 & 37 & 31 \\
Nederlands recht & 1 & 7 & 4 \\
Economie & 612 & 488 & 1100 \\
Totaal $\mathrm{n}(=100 \%)$ & & & 4 \\
\hline
\end{tabular}

$($ Chi-kwadraat $=103.6$, d.f. $=3, p<.01)$

Binnen gezondheidswetenschappen kunnen een zevental afstudeervarianten worden gevolgd:

- beleid en beheer van gezondheidszorgvoorzieningen (BB);

- gezondheidsvoorlichting en -opvoeding (GVO);

- verplegingswetenschap (VW);

- bewegingswetenschappen (BW);

- biologische gezondheidkunde (BGK);

- filosofie en theorie der gezondheidswetenschappen (FT);

- geestelijke gezondheidkunde (GGK).

Tabel 12. Afstudeervariant binnen gezondheidswetenschappen, naar geslacht (in \%)

\begin{tabular}{|c|c|c|c|}
\hline Afstudeervariant & Vrouw & Man & Totaal \\
\hline Beleid en Beheer & 31 & 41 & 34 \\
\hline Gezondheidsvoor- & 26 & 13 & 23 \\
\hline lichting en -opvoeding & & & \\
\hline Verplegingswetenschap & 21 & 18 & 20 \\
\hline Overig & 22 & 28 & 23 \\
\hline Totaal n (=100\%) & 290 & 95 & 385 \\
\hline
\end{tabular}

(Chi-kwadraat $=9.6$, d.f. $=4, p<.05)$

In tabel 12 wordt weergegeven in hoeverre mannen en vrouwen verschillen met betrekking tot de keuze voor deze afstudeervarianten. In deze tabel worden alleen de drie oudste 
afstudeerrichtingen met naam genoemd waarbinnen ruim driekwart van de geënquêteerde gezondheidswetenschappers is afgestudeerd.

Mannen kiezen niet alleen vaker dan vrouwen voor de studierichting economie, ze kiezen ook significant vaker voor de economisch gerichte variant Beleid en Beheer binnen de studierichting gezondheidswetenschappen. Vrouwen kiezen vaker voor de richting Gezondheidsvoorlichting en -opvoeding.

Alvorens na de afronding van de studie aan de $R L$ de arbeidsmarkt te betreden (arbeidsmarktintrede), hebben studenten vaak al arbeidsmarktrelevante ervaring opgedaan. In tabel IV van bijlage I wordt weergegeven in hoeverre er sexeverschillen zijn met betrekking tot werk- en bestuurservaring. Bij werkervaring wordt achtereenvolgens gekeken naar alle vormen van betaalde werkervaring, naar werkervaring binnen en buiten het vakgebied en naar studentassistentschappen. Opgemerkt dient te worden dat de tabel geconstrueerd is op basis van een vraag waar de respondenten meerdere antwoorden op mochten geven. Het is dus goed mogelijk dat een respondent opgeeft zowel werkervaring binnen als buiten het vakgebied te hebben opgedaan.

Op basis van de cijfers in tabel IV kan worden geconstateerd dat er tussen mannen en vrouwen een significant verschil bestaat met betrekking tot het al dan niet opgedaan hebben van werkervaring. Dit verschil is met name groot bij oud-studenten van de Faculteit der Geneeskunde. Mannen hebben vaker betaalde werkervaring opgedaan dan vrouwen. Het gaat hierbij met name om werkervaring buiten het vakgebied. $\mathrm{Er}$ is geen significant verschil tussen mannen en vrouwen met betrekking tot studentassistentschappen en bestuurservaring.

\subsection{Sexediscrepanties in arbeidsmarktintrede en huidige arbeidsmarktpositie}

Het verloop van de intrede op de arbeidsmarkt van academici kan gekarakteriseerd worden door de duur van de intredewerkloosheid en door de verandering in arbeidssituatie. Eerst wordt ingegaan op de intredewerkloosheid, dit wil zeggen het aantal maanden dat men tussen afstuderen en de eerste betaalde baan werkloos is geweest. Daarna komt de verandering in arbeidssituatie tijdens het eerste jaar na afstuderen ter sprake.

\section{Intredewerkloosheid}

Het is niet mogelijk exact aan te geven wat de duur van de intredewerkloosheid bedraagt. Dit heeft te maken met het feit dat wanneer een respondent opgeeft op het moment van bevraging 
werkloos te zijn, niet bekend is wanneer deze toestand zal worden beëindigd. Er is dan sprake van een onvoltooide duur. Beekman en De Grip (1991) presenteren schattingen van de werkloosheidsduur naar opleidingstype met behulp van een 'proportional hazards'-model. In Ramaekers en Heijke (1991) wordt een dergelijke analyse uitgevoerd op het bestand van de RL. De schattingsresultaten wijzen niet op een significant effect van de variabele geslacht op de hazard: mannen hebben geen grotere kans om uit de toestand van werkloosheid te geraken dan vrouwen, of omgekeerd (Ramaekers en Heijke, 1991).

\section{Arbeidssituatie}

In tabel $V$ van bijlage I wordt het percentage studenten weergegeven dat 1, 3, 6 en 12 maanden na afstuderen een betaalde baan heeft weten te vinden.

Uit de tabel kan worden opgemaakt dat alleen bij geneeskunde na 6 en 12 maanden een duidelijk significant verschil optreedt tussen mannen en vrouwen. Na 6 maanden is het percentage dat een baan heeft gevonden bij vrouwen 80.5, terwijl de mannen daar fors achter blijven met $61.5 \%$. In iets mindere mate doet zich dit voor bij gezondheidswetenschappen, waar het verschil tussen vrouwen en mannen ongeveer $10 \%$ bedraagt. Indien alle faculteiten tezamen in ogenschouw worden genomen kunnen er geen significante verschillen tussen mannen en vrouwen worden geconstateerd. Opgemerkt moet worden dat het vervullen van militaire dienst door mannen hierbij een rol kan spelen.

\section{Wijze van functieverwerving}

De wijze waarop de eerste betaalde functie na afstuderen is verkregen, wordt in tabel VI van bijlage I per faculteit naar geslacht weergegeven. Hierin komt naar voren dat de verschillen tussen mannen en vrouwen bij de afzonderlijke faculteiten niet significant zijn. Voor de totale steekproef zijn de verschillen bijna significant. Vrouwen vinden iets vaker hun eerste baan door op vacature-advertenties te solliciteren.

\section{Maatschappelijke positie}

In de enquête is gevraagd naar de situatie die volgens de respondenten hun huidige maatschappelijke positie het beste weergeeft. In tabel 13 worden de verschillen tussen mannen en vrouwen per faculteit weergegeven. 
$-19-$

Tabel 13. Huidige maatschappelijke positie, per faculteit naar geslacht (in \%)

\begin{tabular}{|c|c|c|c|c|c|c|c|c|}
\hline \multirow[b]{2}{*}{ Maatschappelijke positie } & \multicolumn{2}{|c|}{ FdG } & \multicolumn{2}{|c|}{ FdGW } & \multicolumn{2}{|c|}{ FdR } & \multicolumn{2}{|c|}{ Totaal } \\
\hline & vrouw & $\operatorname{man}$ & vrouw & man & vrouw & man & vrouw & Man \\
\hline Betaald werk & 93 & 86 & 84 & 82 & 70 & 72 & 83 & 80 \\
\hline Dienstplichtig & 0 & 9 & 0 & 7 & 0 & 6 & 0 & 7 \\
\hline Fulltime onderwijs & 0 & 1 & 6 & 4 & 13 & 7 & 7 & 4 \\
\hline Huisvrouw/-man & 1 & 0 & 2 & 0 & 1 & 1 & 2 & 0 \\
\hline Arbeidsongeschikt & 0 & 0 & 0 & 1 & 1 & 0 & 0 & 0 \\
\hline Onbetaald werk & 1 & 0 & 3 & 0 & 2 & 3 & 2 & 1 \\
\hline Werkloos & 3 & 5 & 3 & 5 & 10 & 9 & 5 & 7 \\
\hline Overig & 2 & 0 & 1 & 0 & 2 & 2 & 2 & 1 \\
\hline Totaal $n(=100 \%)$ & 149 & 181 & 290 & 95 & 164 & 179 & 612 & 488 \\
\hline Chi-kwadraat & 21.1 & & 31.8 & & 14.8 & & 56.0 & \\
\hline
\end{tabular}

* = significant op $5 \%$ niveau

Uit tabel 13 blijkt dat de verschillen tussen mannen en vrouwen significant zijn. Ook blijkt dat de meeste respondenten op het moment van de enquete betaald werk verrichten. Aangezien de percentages in de andere categorieën gering zijn, is ook een analyse uitgevoerd waarbij alleen tussen betaald werk en geen betaald werk een opsplitising is gemaakt. Deze analyse, die hier niet is weergegeven, had als uitkomst dat er geen significante verschillen tussen mannen en vrouwen zijn met betrekking tot het al dan niet vervullen van een betaalde baan. Het zijn daarom de verschillen tussen mannen en vrouwen in de categorieën 'dienstplichtig' tot en met 'overig' die zorgen voor een significante chi-kwadraat. Mannen vervullen militaire dienstplicht, vrouwen volgen vaker voltijds-dagonderwijs en dragen vaker zorg voor de huishouding.

\subsection{Sexediscrepanties in beroepsuitoefening}

In deze paragraaf wordt eerst ingegaan op de stabiliteit van de huidige functie. Vervolgens worden de functies getypeerd aan de hand van de werkorganisaties waarin men terecht is gekomen, het beroep dat men uitoefent, het niveau en de aansluiting met de genoten opleiding.

\subsubsection{Baanstabiliteit}

Baanstabiliteit verwijst naar twee kenmerken van de aanstelling in loondienst. In de eerste plaats het aantal maanden waarop de formele aanstelling in loondienst betrekking heeft. Deze variabele wordt geoperationaliseerd door twee waarden: een tijdelijk dienstverband (een dienstverband voor minder dan 5 jaar) en een vast dienstverband (dienstverband voor langer 
dan 5 jaar). Ook de lengte van de werkweek biedt een indicatie voor de stabiliteit van de baan. Hierbij kan een onderscheid tussen full-time (een meer dan 34 urige werkweek) en part-time functies wordt gemaakt. Alvorens de baanstabiliteit te bespreken wordt in het kort iets gezegd over het soort dienstverband waarin men werkt.

\section{Dienstverband}

Het soort dienstverband, waarbij een onderscheid wordt gemaakt tussen werken in loondienst en werken voor eigen risico of rekening (als zelfstandige), wordt in tabel VII van bijlage I weergegeven. Hierin komt naar voren dat alleen bij oud-studenten van de Faculteit der Rechtsgeleerdheid mannen en vrouwen significant verschillen met betrekking tot het soort dienstverband. Mannelijke juristen werken vaker als zelfstandige dan vrouwen.

\section{Baanstabiliteit}

In tabel 14 komt naar voren dat er geen significante verschillen zijn in de mate waarin mannen en vrouwen een vaste aanstelling weten te verwerven.

Tabel 14. Percentage respondenten met een vaste aanstelling, per faculteit naar geslacht

\begin{tabular}{lcccc}
\hline Faculteit & Vrouw & Man & Totaal & Chi-kwadraat \\
\hline FdG & 10 & 14 & 12 & 1 \\
FDGW & 23 & 27 & 24 & 1 \\
FdR & 23 & 31 & 27 & 3 \\
RL & 20 & 25 & 22 & 3 \\
\hline
\end{tabular}

In tabel 15 wordt per faculteit het percentage respondenten met een full-time baan weergegeven. Naar voren komt dat het aantal full-time banen bij mannen beduidend hoger ligt. De verschillen zijn significant, behalve voor de Faculteit der Rechtsgeleerdheid. 
Tabel 15. Percentage respondenten met een full-time baan, per faculteit naar geslacht

\begin{tabular}{|c|c|c|c|c|}
\hline Faculteit & Vrouw & Man & Totaal & Chi-kwadraat \\
\hline FdG & 77 & 89 & 83 & $8 *$ \\
\hline FdGW & 71 & 89 & 75 & $10 *$ \\
\hline $\mathrm{FdR}$ & 84 & 90 & 87 & 2 \\
\hline RL & 76 & 89 & 82 & $26 *$ \\
\hline
\end{tabular}

* = significant op $5 \%$ niveau

\subsubsection{Werkorganisaties}

De werkorganisaties waarin men terecht is gekomen, worden achtereenvolgens getypeerd naar grootte, geografische lokatie en bedrijfstak.

\section{Grootte}

De omvang van de werkorganisatie is voor mannen en vrouwen niet significant verschillend. Tabel VIII in bijlage I geeft daar inzicht in.

\section{Lokatie}

In tabel IX van bijlage I wordt de regio waarin men werkt weergegeven. Uit de tabel blijkt dat vrouwen significant vaker in provincies buiten Limburg terecht komen dan mannen. Voor de afzonderlijke faculteiten zijn de verschillen niet significant.

\section{Bedrijfstak}

De bedrijfstakken waarin men werkt, worden in tabel 16 vermeld. Uit de tabel blijkt dat vrouwen vaker in de kwartaire sector (non-profit) terecht komen, terwijl mannen vaker in de tertiaire sector (zakelijke dienstverlening) werken. De verschillen zijn echter alleen voor de RL als geheel, dus niet per faculteit, significant. 
Tabel 16. Betaald werkende oud-studenten naar bedrijfstak, in \%

\begin{tabular}{|c|c|c|c|c|c|c|c|c|}
\hline \multirow[t]{2}{*}{ Bedrijfstak } & \multicolumn{2}{|c|}{ FdG } & \multicolumn{2}{|c|}{ FdGW } & \multicolumn{2}{|c|}{$\mathrm{FdR}$} & \multicolumn{2}{|c|}{$\mathrm{RL}$} \\
\hline & vrouw & man & vrouw & man & vrouw & $\operatorname{man}$ & vrouw & man \\
\hline Primaire sector & 0 & 0 & 0 & 0 & 0 & 1 & 0 & 0 \\
\hline Secundaire sector & 0 & 3 & 5 & 8 & 2 & 5 & 3 & 6 \\
\hline Tertiaire sector & 1 & 2 & 9 & 12 & 33 & 39 & 14 & 20 \\
\hline Kwartaire sector & 99 & 96 & 86 & 80 & 65 & 56 & 83 & 74 \\
\hline Totaal n ( $=100 \%)$ & 139 & 156 & 244 & 78 & 115 & 129 & 508 & 390 \\
\hline Chi-kwadraat & 4.9 & & 2.7 & & 1.1 & & 13.6 * & \\
\hline
\end{tabular}

* = significant op $5 \%$ niveau

\subsubsection{Beroep en branche}

Tabel 17 geeft een beeld van de (omvang van de) uitwijkmogelijkheden naar andere beroepsgroepen (3-digit niveau volgens de Beroepenclassificatie van het CBS) en bedrijfsgroepen (3-digit niveau volgens de Standaard Bedrijfsindeling van het CBS) die mannen en vrouwen hebben.

Tabel 17. De beroepsgroepen- en bedrijfsgroepenspreiding naar studie/afstudeerrichting en geslacht (GiniHirschman coëfficiënten)

\begin{tabular}{|c|c|c|c|c|}
\hline \multirow[b]{2}{*}{ Opleidingsrichting } & \multicolumn{2}{|c|}{ Beroepsgroepenspreiding } & \multicolumn{2}{|c|}{ Bedrijfsgroepenspreiding } \\
\hline & vrouw & man & vrouw & man \\
\hline Geneeskunde & 0,26 & 0,27 & 0,80 & 0,75 \\
\hline BB & 0,88 & 0,91 & 0,88 & 0,86 \\
\hline GVO & 0,68 & 0,78 & 0,78 & 0,76 \\
\hline VW & 0,89 & 0,84 & 0,86 & 0,80 \\
\hline Rechten & 0,76 & 0,80 & 0,87 & 0,89 \\
\hline Economie & 0,53 & 0,77 & 0,67 & 0,78 \\
\hline
\end{tabular}

In tabel 17 komt naar voren dat mannen doorgaans iets meer uitwijkmogelijkheden naar andere beroepen hebben dan vrouwen. Dit is met name bij economie en GVO het geval. Met betrekking tot de branchespreiding doet zich de omgekeerde situatie voor, namelijk dat vrouwen door de bank genomen iets meer uitwijkmogelijkheden naar andere bedrijfsgroepen hebben dan mannen. Dit is met name bij de richtingen VW en geneeskunde het geval. 
Zowel voor de beroepen als de bedrijfssubgroepen zijn segregatie-indices berekend. De segregatie-index (s) geeft de som aan van de respectievelijke aandelen van de mannelijke en vrouwelijke populatie die van beroep of bedrijfsgroep zouden moeten veranderen ten einde de segregatie op te heffen. Bij de gecorrigeerde index (S) wordt dit percentage berekend onder de restrictie dat de verdeling van de populatie over de beroepen c.q. bedrijfsgroepen ongewijzigd blijft. Deze indices worden in tabel 18 weergegeven.

Tabel 18. Segregatie-indices voor beroepen en bedrijfssubgroepen, naar faculteit

\begin{tabular}{|c|c|c|c|c|}
\hline \multirow[b]{2}{*}{ Faculteit } & \multicolumn{2}{|c|}{ Beroepen } & \multicolumn{2}{|c|}{ Bedrijfssubgroepen } \\
\hline & s & $\mathrm{S}$ & $\mathrm{s}$ & $\mathrm{S}$ \\
\hline FdG & 7 & 3.5 & 11.2 & 5.6 \\
\hline FdGW & 15.9 & 5.8 & 2.4 & 0.88 \\
\hline FdR & 17.6 & 8.8 & 16.8 & 8.4 \\
\hline
\end{tabular}

De sexesegregatie in uitgeoefende beroepen is het kleinst bij geneeskunde. De sexesegregatie in bedrijfsgroepen waarin men terecht komt is het kleinst bij gezondheidswetenschappen. In de tabellen $\mathrm{Xa}$ tot en met XIlb van bijlage I wordt weergegeven in welke beroepen en bedrijfssubgroepen de afgestudeerden terecht zijn gekomen.

\subsubsection{Functieniveau}

Het niveau van de huidige functie wordt in deze subparagraaf achtereenvolgens vanuit twee invalshoeken benaderd. Eerst door na te gaan of men al dan niet leiding geeft en vervolgens door het genoten inkomen te beschouwen. Hierbij dient te worden bedacht dat het gaat om academici die nog aan het begin van hun beroepsloopbaan staan. In de volgende subparagraaf wordt het functieniveau benaderd door te kijken naar het niveau van de opleiding dat voor de uitoefening van de functie is vereist.

\section{Leidinggeven}

In tabel 19 wordt weergegeven in hoeverre de respondenten een leidinggevende positie innemen in de huidige baan. Hierin komt naar voren dat mannen significant vaker werkzaam zijn in leidinggevende posities. De verschillen zijn voor iedere faculteit significant. 
$-24-$

Tabel 19. Percentage respondenten dat een leidinggevende functie uitoefent, per faculteit naar geslacht

\begin{tabular}{|c|c|c|c|c|}
\hline Faculteit & Vrouw & Man & Totaal & Chi-kwadraat \\
\hline FdG & 28 & 42 & 35 & $7 *$ \\
\hline FdGW & 20 & 31 & 23 & $4^{*}$ \\
\hline FdR & 17 & 37 & 28 & $11^{*}$ \\
\hline $\mathrm{RL}$ & 22 & 37 & 28 & $26 *$ \\
\hline
\end{tabular}

* = significant op $5 \%$ niveau

\section{Inkomen}

Naast het al dan niet leiding geven biedt ook het inkomen een indicatie voor het niveau van de functie. In tabel 20 wordt het bruto maandinkomen (bij een volledige werkweek) in de huidige betaalde functie per faculteit naar geslacht weergegeven.

Tabel 20. Bruto maandinkomen bij een volledige werkweek, per faculteit naar geslacht (in \%)

\begin{tabular}{|c|c|c|c|c|c|c|c|c|}
\hline \multirow[b]{2}{*}{ Inkomen } & \multicolumn{2}{|c|}{ FdG } & \multicolumn{2}{|c|}{ FdGW } & \multicolumn{2}{|c|}{ FdR } & \multicolumn{2}{|l|}{$\mathrm{RL}$} \\
\hline & vrouw & man & vrouw & $\operatorname{man}$ & vrouw & $\operatorname{man}$ & vrouw & man \\
\hline$<f 2.000$ & 9 & 3 & 5 & 5 & 3 & 6 & 7 & 5 \\
\hline$f 2000-f 2.500$ & 4 & 8 & 9 & 8 & 8 & 9 & 8 & 9 \\
\hline$f 2.500-f 3.000$ & 7 & 8 & 9 & 5 & 20 & 11 & 11 & 8 \\
\hline$f 3.000-f 3.750$ & 15 & 5 & 40 & 33 & 39 & 35 & 33 & 23 \\
\hline$f 3.000-f 5.000$ & 54 & 51 & 33 & 36 & 28 & 27 & 37 & 38 \\
\hline$>f 5.000$ & 1 & 26 & 4 & 13 & 3 & 12 & 5 & 16 \\
\hline Totaal n (=100\%) & 139 & 156 & 244 & 78 & 115 & 129 & 508 & 390 \\
\hline Chi-kwadraat & 25. & & 17. & & 14.4 & & $37.7^{*}$ & \\
\hline
\end{tabular}

* = significant op $5 \%$ niveau

In deze tabel komt tot uitdrukking dat mannen vaker een inkomen in de hoogste inkomensklasse hebben, terwijl vrouwen in de klassen met inkomens tussen $f 2.500,--$ en $f 3.750,--$ oververtegenwoordigd zijn.

\subsubsection{Aansluiting onderwijs en functie}

Gepoogd wordt om de aansluiting van de gevolgde studie met de uitgeoefende functie inzichtelijk te maken aan de hand van achtereenvolgens het niveau en de richting van de vereiste opleiding en eventueel later gevolgd onderwijs na afstuderen. 


\section{Opleidingseisen}

De opleidingseisen die gesteld worden bij de huidige baan, geven niet alleen een indicatie voor het niveau van de functie, en daarmee voor eventuele concurrentie tussen academici en in lagere onderwijsniveaus opgeleiden, maar ook voor de mate waarin afgestudeerden van de RLstudierichtingen op de arbeidsmarkt concurrentie kunnen ondervinden van afgestudeerden in andere studierichtingen op academisch niveau.

Wanneer de vereiste opleiding onder universitair niveau ligt is er niet alleen sprake van concurrentie tussen academisch opgeleiden en in andere onderwijsniveaus opgeleiden, maar ook van onderbenutting van capaciteiten bij de uitoefening van de functie. Uit tabel 21 blijkt dat er weinig sprake is van onderbenutting. De meeste respondenten oefenen functies uit die voor academici zijn bestemd. Hierbij zijn de verschillen tussen mannen en vrouwen niet significant.

Tabel 21. Percentage banen met WO als vereist opleidingsniveau, per faculteit naar geslacht

\begin{tabular}{|c|c|c|c|c|}
\hline Faculteit & Vrouw & Man & Totaal & Chi-kwadraat \\
\hline FdG & 98 & 99 & 99 & 0.41 \\
\hline FdGW & 73 & 78 & 74 & 0.67 \\
\hline FdR & 84 & 76 & 80 & 1.72 \\
\hline RL & 89 & 86 & 84 & 1.19 \\
\hline
\end{tabular}

Tabel 22. Percentage banen op academisch niveau waarvoor de gevolgde studierichting specifiek is vereist, per faculteit naar geslacht

\begin{tabular}{lcccc}
\hline & Vrouw & Man & Totaal & Chi-kwadraat \\
\hline FdG & 94 & 91 & 93 & 0.35 \\
FdGW & 37 & 44 & 39 & 0.58 \\
FdR & 84 & 80 & 82 & 0.23 \\
RL & 68 & 77 & 72 & $5.06^{*}$ \\
\hline
\end{tabular}

* = significant op $5 \%$ niveau

Tabel 22 geeft een beeld van de mate waarin afgestudeerden van de beschouwde RLstudierichtingen concurrentie kunnen ondervinden van afgestudeerden in andere studierichtingen op academisch niveau. Hierin komt naar voren dat mannen significant vaker dan vrouwen in functies werken waarvoor de gevolgde studierichting specifiek is vereist. Het verschil is echter geheel te herleiden tot een afwijkende sexeratio per faculteit. 


\section{Aanvullend onderwijs}

In tabel 23 wordt weergegeven in hoeverre de respondenten aanvullend onderwijs volgen of hebben gevolgd.

Tabel 23. Percentage respondenten dat aanvullend onderwijs volgt, per faculteit naar geslacht

\begin{tabular}{lcccc}
\hline Faculteit & Vrouw & Man & Totaal & Chi-kwadraat \\
\hline FdG & 69 & 70 & 69 & 0.1 \\
FdGW & 68 & 53 & 64 & $6.9^{*}$ \\
FdR & 74 & 68 & 71 & 1.6 \\
RL & 70 & 66 & 68 & 1.6 \\
\hline
\end{tabular}

$*$ significant op $5 \%$ niveau

Uit tabel 23 blijkt dat de verschillen tussen mannen en vrouwen alleen bij de gezondheidswetenschappers significant zijn. Vrouwelijke gezondheidswetenschappers volgen vaker een aanvullende opleiding.

\subsection{Sexediscrepanties in mobiliteit}

\section{Baanmobiliteit}

In paragraaf 3.4. is een aantal kenmerken van de huidige baan behandeld. In $55 \%$ van deze banen ging het om de eerste baan na afstuderen. Hiervan geeft tabel 24 een beeld. In deze tabel, waarin wordt weergegeven of men al dan niet van werkgever is veranderd, komt naar voren dat de verschillen tussen mannen en vrouwen niet significant zijn.

Tabel 24. Percentage respondenten dat van werkgever is veranderd, per faculteit naar geslacht

\begin{tabular}{lcccc}
\hline Faculteit & Vrouw & Man & Totaal & Chi-kwadraat \\
\hline FdG & 62 & 61 & 61 & 0.1 \\
FdGW & 40 & 31 & 37 & 2.0 \\
FdR & 39 & 39 & 39 & 0.0 \\
RL & 45 & 44 & 45 & 0.1 \\
\hline
\end{tabular}




\section{Potentiële baanmobiliteit}

Door na te gaan hoeveel van de betaald werkende oud-studenten op zoek zijn naar een andere baan worden indicaties verkregen omtrent de potentiële baanmobiliteit. Hiervan geeft tabel 25 een beeld.

Tabel 25. Percentage betaald werkende respondenten dat op zoek is naar een andere baan, per faculteit naar geslacht

\begin{tabular}{lcccc}
\hline Faculteit & Vrouw & Man & Totaal & Chi-kwadraat \\
\hline FdG & 45 & 39 & 40 & 2.9 \\
FdGW & 28 & 23 & 27 & 0.5 \\
FdR & 23 & 24 & 24 & 0.1 \\
RL & 31 & 27 & 29 & 1.2 \\
\hline
\end{tabular}

Uit tabel 25 komt naar voren dat vrouwen niet significant vaker op zoek zijn naar een andere baan dan mannen.

3.6. De betekenis van de factor sexe in de verklaring van de verschillen in arbeidsmarktpositie van afgestudeerden

De bivariate analyses in de voorgaande paragrafen geven verschillen tussen mannen en vrouwen weer met betrekking tot een bepaalde variabele (inkomen, mate van leidinggeven etc.). In hoeverre het geslacht verantwoordelijk is voor de geconstateerde verschillen kan alleen worden bepaald middels multivariate analyses. In deze paragraaf wordt een overzicht gegeven van de multivariate analyses die betrekking hebben op een aantal van de kenmerken die in de voorgaande paragrafen zijn behandeld.

De multivariate analyses zijn uitgevoerd op een aantal te verklaren variabelen (endogenen) die geconstrueerd zijn op basis van een aantal dimensies van de arbeidsmarktpositie. Deze hebben betrekking op de (mate van) participatie aan het arbeidsproces, het niveau van het werk en eventuele verandering van baan.

De volgende dimensies van de arbeidsmarktpositie worden als endogenen in de multivariate analyses betrokken: huidige maatschappelijke positie (zie paragraaf 3.3.), baanzekerheid 
(3.4.1.), werktijdfactor (3.4.1.), leidinggeven (3.4.4.), inkomen (3.4.4.), opleidingseisen (3.4.5.), aanvullende opleiding (3.4.5.), potentiële baanmobiliteit (3.5.) en baanmobiliteit (3.5.). Voor een aantal endogenen, namelijk huidige maatschappelijke positie, baanzekerheid, inkomen en potentiële baanmobiliteit, komen de analyses overeen met de analyses die door Ramaekers en Heijke ten behoeve van de arbeidsmarktscanner voor de Rijksuniversiteit Limburg zijn uitgevoerd (Ramaekers, Heijke, 1991).

De verklarende variabelen bestaan uit een aantal achtergrondkenmerken (geslacht, leeftijd, werk- en bestuurlijke ervaring vóór afstuderen, aantal jaren op de arbeidsmarkt), en kenmerken van de huidige baan (baanzekerheid, werktijdfactor, inkomen, mate van leidinggeven, vereist opleidingsniveau, al dan niet combineren van werken en leren en branche). De operationalisatie van de variabelen wordt in bijlage II beschreven. De schattingsresultaten zijn vermeld in bijlage III.

Met uitzondering van het inkomen zijn alle endogenen binaire variabelen. Dit houdt in dat de kleinste kwadraten schattings-techniek (OLS) geen goede schattingen van de parameters zou opleveren. Deze zogenaamde probit-modellen zijn derhalve met de maximale aannemelijkheidsmethode (maximum likelihood, ML) geschat.

De analyses zijn verricht op het bestand dat respondenten bevat die betaald werk als huidige maatschappelijke positie hebben opgegeven en de thans niet betaald werkende retrospectief bevraagde afgestudeerden die na afstuderen wel betaald hebben gewerkt. Alleen de analyse met betrekking tot het verklaren van de huidige maatschappelijke positie is op het hele bestand verricht.

Allereerst worden de analyses per vergelijking besproken. Daarna wordt een aantal globale conclusies getrokken.

\section{Huidige maatschappelijke positie}

Bij de operationalisatie van de variabele 'huidige maatschappelijke positie', is gekozen voor een binaire variabele, die nul is indien de respondent geen betaalde baan heeft, en één indien dit wel het geval is. Hoewel de kruistabellen weergeven dat juist in deze indeling (wel/niet een baan) geen verschil is te constateren tussen mannen en vrouwen, is om een aantal redenen voor deze operationalisatie gekozen. Ten eerste is het, gezien het onderwerp van het onderzoek, de meest relevante indeling. Ten tweede is bij deze indeling de celvulling redelijk, hetgeen om statistische redenen gewenst is. 
Significant zijn de parameters voor de variabelen rechten, economie, werkervaring en cohort. Dit houdt in dat oud-studenten met rechten als afgeronde opleiding minder vaak een baan hebben (negatief teken). Oud-studenten met economie als opleiding hebben vaker een baan, evenals mensen met werkervaring (gedurende de studie) en mensen die relatief lang geleden zijn afgestudeerd. Er is geen significant verschil tussen mannen en vrouwen.

\section{Baanzekerheid}

Baanzekerheid (het al dan niet hebben van een vaste aanstelling) wordt, evenals de kans op betaald werk, niet significant beïnvloed door het geslacht van de respondent. De kans op een vaste aanstelling blijkt wel groter te zijn wanneer men economie of de economisch gerichte variant binnen gezondheidswetenschappen (BB) heeft gestudeerd.

\section{Werktijdfactor}

Mannen werken significant vaker full-time dan vrouwen. Ouderen werken minder vaak full-time. De multivariate analyse bevestigt hiermee het beeld van de (bivariate) kruistabel. Daarnaast zijn mensen die werken combineren met leren, in de profit-sector werken of in de studietijd werkervaring hebben opgedaan, significant vaker full-time werkzaam.

\section{Leidinggeven}

Mannen zijn significant vaker werkzaam in leidinggevende posities dan vrouwen. Dit bevestigt het beeld van de kruistabel. Daarnaast zijn mensen met werkervaring vóór afstuderen en mensen die reeds langer op de arbeidsmarkt verblijven, relatief vaak in leidinggevende posities te vinden.

\section{Inkomen}

Aan de respondenten is gevraagd wat hun bruto maaninkomen is bij een volledige werkweek. In de vragenlijst zijn 9 inkomensklassen onderscheiden waarvan de hoogste en laagste 'open' zijn. Voor de analyse is de variabele inkomen gedefinieerd als het klassemidden van de zeven 'gesloten' inkomensklassen. Bij de laagste ('open') inkomensklasse is de hoogste waarde gebruikt die $f 1.500,--$ bruto per maand bedraagt. Dit komt ongeveer overeen met het wettelijk minimum loon. Het voorgaande impliceert dat de variabele inkomen de volgende waarden kan aannemen: 
$-f 1.750,--$

$-f 2.250,--$

- $f$ 2.750,--

- $f 3.375,--$

- $f$ 4.375,--

$-f 6.250,--$

$-f 10.000,--^{2}$

Uit de schattingsresultaten blijkt dat mannen significant meer verdienen dan vrouwen. De waarde van de geschatte parameter - 266,05 - geeft het bedrag in guldens aan dat mannen meer verdienen dan vrouwen.

Oud-studenten geneeskunde en beleid en beheer verdienen significant meer dan studenten van andere studierichtingen. Hetzelfde geldt voor mensen die relatief lang participeren op de arbeidsmarkt. leder additioneel jaar op de arbeidsmarkt brengt bruto ruim $f$ 200,-- extra per maand op. Ook de grootte van de organisatie speelt een rol. In grote organisaties wordt meer verdiend dan in middelgrote of kleine organisaties.

Een aantal kenmerken van de huidige arbeidsovereenkomst heeft een significante invloed op het verdiende inkomen. In een vast dienstverband is het inkomen hoger dan in een tijdelijke aanstelling. Afgestudeerden die leiding geven, verdienen meer dan afgestudeerden die dat niet doen. Afgestudeerden die een functie uitoefenen waarvoor een wetenschappelijke opleiding vereist is, verdienen meer dan afgestudeerden die onder hun niveau werken. Diegenen die werken combineren met leren verdienen significant minder dan afgestudeerden die dat niet doen. Het gaat hierbij om assistenten in opleiding (AIO's) en assistent-geneeskundigen in opleiding (AGIO's).

\section{Opleidingseisen}

Mensen die betaald werken combineren met verder leren en/of in de non-profit sector werken, hebben significant vaker een baan waarvoor een wetenschappelijke opleiding is vereist. Dit is ook het geval wanneer men geneeskunde heeft gestudeerd. Geslacht speelt geen significante rol.

2. Dezelfde analyse, verricht met de logarithmische transformatie van de variabele inkomen, leidde niet tot andere schattingsresultaten. 


\section{Aanvullend onderwijs}

Het geslacht van de respondent heeft geen significant invloed op het volgen van een aanvullende opleiding. Oud-economie studenten, mensen met bestuurservaring gedurende de studietijd en jonge mensen volgen significant vaker een aanvullende opleiding dan anderen.

\section{Baanmobiliteit}

Oud-studenten geneeskunde, beleid en beheer, verplegingswetenschap en rechten zijn relatief vaak van baan veranderd.

\section{Potentiële baanmobilitiet}

Oud-studenten geneeskunde zijn significant vaker op zoek naar ander werk dan afgestudeerden van andere opleidingen. Aannemelijk is dat zij op zoek zijn naar een opleidingsplaats voor medisch specialist. Wanneer men werken combineert met leren, een vaste aanstelling of een goed op de gevolgde opleiding aansluitende functie heeft, is men minder genegen van baan te veranderen. $\mathrm{Er}$ is geen significant verschil tussen mannen en vrouwen met betrekking tot de geneigdheid van baan te veranderen.

\section{Conclusies}

De multivariate analyses bevestigen het beeld dat reeds in de kruistabellen naar voren kwam, namelijk dat de variabele geslacht doorgaans geen significante rol speelt bij de verklaring van de onderscheiden dimensies van de arbeidsmarktpositie. Een uitzondering vormen de vergelijkingen voor het inkomen, de werktijdfactor en de mate van leidinggeven. Mannen blijken vaker dan vrouwen in leidinggevende functies werkzaam te zijn; ze hebben vaker een full-time baan en verdienen meer.

Aangezien een maatstaf als de R-kwadraat (percentage verklaarde variantie) voor de meeste analyses ontbreekt, de vergelijking voor het inkomen uitgezonderd, is bij de analyses met binaire endogenen (de te verklaren grootheid is nul of één) een andere maatstaf gebruikt voor de evaluatie van de vergelijkingen. Dit betreft de (ex-post) voorspelkracht van de vergelijkingen. In tabel 27 wordt de voorspelkracht van het model vergeleken met de voorspelkracht van een strategie die kan worden toegepast indien alleen wordt beschikt over waarnemingen van de endogenen (basisvoorspelling). 
Tabel 27. Percentage goed voorspelde waarnemingen

\begin{tabular}{|c|c|c|c|}
\hline Vergelijking & Voorspelkracht & Basisvoorspelling & R-kwadraat \\
\hline Huidige maatschappelijke positie & 81.5 & 0.70 & \\
\hline Baanzekerheid & 76.2 & 0.66 & \\
\hline Werktijdfactor & 82.5 & 0.72 & \\
\hline Leidinggeven & 67.3 & 0.52 & \\
\hline Inkomen & & & 0.22 \\
\hline Opleidingseisen & 82.1 & 0.73 & \\
\hline Aanvullende opleiding & 68.7 & 0.57 & \\
\hline Potentiële baanmobiliteit & 75.1 & 0.53 & \\
\hline Verandering werkgever & 62.3 & 0.53 & \\
\hline
\end{tabular}

Op basis van het model worden de waarnemingen met ongeveer $10 \%$ tot $20 \%$ beter voorspeld dan de voorspellingen die op basis van louter de waarnemingen plaatsvinden. 


\section{CONCLUSIES}

Op basis van zowel landelijke gegevens als gegevens met betrekking tot afgestudeerden van de $\mathrm{RL}$ is per WO-studierichting beschreven in hoeverre mannen en vrouwen verschillend scoren op een aantal dimensies van de arbeidsmarktpositie. Vervolgens is nagegaan of het geslacht als autonome factor verantwoordelijk is voor de geconstateerde verschillen, of dat deze moeten worden toegeschreven aan mogelijk interveniërende variabelen.

In de inleiding is een aantal sexediscrepanties genoemd, die zich volgens Bruyn-Hundt op de arbeidsmarkt voordoen. Dit hoofdstuk beschrijft de onderzoeksbevindingen aan de hand van de constateringen die door Bruyn-Hundt zijn gemaakt. Op deze wijze kan worden nagegaan of deze constateringen ook van toepassing zijn op dat deel van de arbeidsmarkt waar recent afgestudeerden van de RL actief zijn. Telkens wordt eerst de constatering van Bruyn-Hundt geciteerd, gevolgd door de desbetreffende conclusie van dit onderzoek.

Bruyn-Hundt: 'vrouwen ontbreken op de arbeidsmarkt omdat er kleine kinderen verzorgd moeten worden'.

Uit de landelijke gegevens komt inderdaad naar voren dat over het geheel genomen vrouwelijke academici in mindere mate aan het arbeidsproces deelnemen dan mannen. In de jaren tachtig is de voorsprong van mannen met betrekking tot de participatie aan het arbeidsproces bij de economische en juridische studierichtingen duidelijk afgenomen. Bij de medische studierichtingen daarentegen nam de voorsprong van mannen toe. Bij alle nader beschouwde WOstudierichtingen is het aandeel van de mannelijke beroepsbevolking afgenomen. Bij de medische studierichtingen daalde echter ook het aandeel van vrouwen dat zich aanbiedt op de arbeidsmarkt. Met betrekking tot de landelijke cijfers zijn geen causale analyses uitgevoerd, zodat niet duidelijk is in hoeverre de aanwezigheid van kinderen een rol speelt bij de geringere arbeidsmarktparticipatie van vrouwen. Uit de analyses die op het RL-bestand zijn uitgevoerd, blijkt dat mannen en vrouwen niet significant verschillen met betrekking tot de mate waarin zij aan het arbeidsproces deelnemen.

Bruyn-Hundt: 'vrouwen werken vaker in deeltijd'.

Deze constatering wordt zowel door landelijke gegevens als door de gegevens over afgestudeerden van de $\mathrm{RL}$ bevestigd. Bij alle studierichtingen zien we dat vrouwen significant vaker in deeltijd werken dan mannen. 
Bruyn-Hundt: 'de opleiding van vrouwen is minder beroepsgericht'.

Uit de landelijke gegevens komt naar voren dat hoewel de achterstand van vrouwen in de uitstroom uit het WO steeds kleiner wordt, zij nog steeds voor andere studierichtingen kiezen dan mannen. Het aandeel van vrouwen in de uitstroom uit het WO neemt bij de nader beschouwde studierichtingen, met uitzondering van gezondheidswetenschappen, gestaag toe. $\mathrm{Nu}$ al komen jaarlijks meer vrouwelijke geneeskundigen beschikbaar voor de arbeidsmarkt dan mannelijke artsen. Verwacht wordt dat rond de eeuwwisseling jaarlijks even veel vrouwelijke als mannelijke juristen afstuderen. Bij gezondheidswetenschappen blijven vrouwen een stabiel grote meerderheid vormen. Bij de afgestudeerde economen zullen vrouwen echter nog zeer lang ondervertegenwoordigd zijn. Uit het onderhavige onderzoek zijn geen conclusies te trekken met betrekking tot de beroepsgerichtheid van opleidingen die met name door vrouwen gekozen worden.

Bruyn-Hundt: 'vrouwen werken in 'vrouwenberoepen', waardoor zij geconcentreerd zijn in een geringer aantal beroepen en sectoren dan mannen'.

De beroepssegregatie-indices wijzen erop dat vrouwen deels in andere beroepen terecht komen dan mannen. Vrouwen zijn inderdaad doorgaans in een geringer aantal beroepen geconcentreerd dan mannen. Dit is zowel landelijk als bij de RL het geval. Uit de landelijke gegevens komt bovendien naar voren dat vrouwen vaker dan mannen terecht komen in beroepsklassen met slechte arbeidsmarktperspectieven.

Zowel uit de landelijke gegevens als uit het RL-bestand blijkt dat de beroepssegregatie bij geneeskunde het laagst is. Bij deze studierichting is evenwel het verschil in spreiding over beroepen tussen mannen en vrouwen gering. Sexeverschillen in spreiding over branches zijn door de bank genomen gering.

Bruyn-Hundt: 'in hogere functieniveaus ontbreken vrouwen nagenoeg geheel'.

Uit de landelijke gegevens met betrekking tot academisch opgeleiden blijkt dat alleen onder economen het gemiddeld beroepsniveau van vrouwen lager is dan van mannen. De analyses die zijn verricht op het RL-bestand tonen aan dat mannen en vrouwen niet significant verschillen ten aanzien van het opleidingsniveau dat voor hun functie is vereist. Wel blijken mannelijke afgestudeerden van de RL significant vaker dan vrouwen in leidinggevende functies werkzaam te zijn. 
Bruyn-Hundt: 'de werkloosheid onder vrouwen is hoger dan die onder mannen, vooral als rekening wordt gehouden met de 'verborgen' werkloosheid'.

Uit de landelijke gegevens blijkt dat over het gehele WO genomen vrouwelijke academische schoolverlaters inderdaad vaker werkloos zijn dan mannen. De studierichting geneeskunde geeft echter het omgekeerde beeld te zien.

Het onderzoek onder afgestudeerden van de RL wijst er niet op dat meer vrouwen werkloos zijn dan mannen. Ook blijkt dat het geslacht geen significant effect heeft op de kans om uit de toestand van werkloosheid te geraken.

Bruyn-Hundt: 'vrouwen hebben een lager uurloon dan mannen'.

Deze constatering wordt bevestigd door de bevindingen onder oud-studenten van de RL. Geschat wordt dat mannen circa fl 250,00 bruto per maand meer verdienen dan vrouwen, gemeten bij een normale werkweek.

Bruyn-Hundt: 'een deel van dit verschil kan niet door objectieve factoren zoals leeftijd, opleiding e.d. verklaard worden, maar moet worden toegeschreven aan discriminatie'.

In onze analyses kwam naar voren dat het geslacht van academici bij de verklaring van de meeste dimensies van de arbeidsmarktpositie geen significante rol speelt. Het geslacht blijkt alleen van invloed te zijn op het werken in deeltijd dan wel voltijd, het al dan niet uitoefenen van een leidinggevende functie en het inkomen. Gebleken is dat vrouwen vaker dan mannen in deeltijd werken. Mannen oefenen daarentegen vaker een leidinggevende functie uit en verwerven een hoger inkomen. Resteert de vraag of de sexeverschillen bij het al dan niet in deeltijd werken, het al dan niet leiding geven en het inkomen moeten worden toegeschreven aan discriminatie van vrouwen op de arbeidsmarkt of aan zelfselectie. Het is aannemelijk dat vrouwen er bewust voor kiezen om in deeltijd te werken. Er is immers niet gebleken dat vrouwen vaker dan mannen werkloos zijn en daardoor gedwongen zijn om hun toevlucht te zoeken tot tijdelijk, slecht betaald deeltijdwerk van een laag niveau. Bij de constatering dat vrouwen minder vaak in leidinggevende functies terechtkomen kan zelfselectie maar ook discriminatie een rol spelen. Indien in de opleiding van vrouwen (meer) aandacht wordt geschonken aan het aspect 'leiding geven', zou hiervan wel eens een positieve invloed kunnen uitgaan op het aandeel van vrouwen in leidinggevende functies. Het geconstateerde verschil in inkomen wijst in de richting van discriminatie. Immers, in de analyse van het inkomen, dat gemeten is bij een normale werkweek, is gecorrigeerd voor het feit dat mannen vaker een leidinggevende functie uitoefenen. 


\section{LITERATUUR}

Beekman, Th. B.J., A. de Grip (1991), Werkloosheidsindicatoren voor schoolverlaters, ROA-RM1991/1, Maastricht.

Bruyn-Hundt, M. (1988), Vrouwen op de arbeidsmarkt, Utrecht.

CBS (1984), Beroepenclassificatie 1984, Voorburg.

CBS (1991), Enquete Beroepsbevolking 1990, Voorburg/Heerlen.

Dam, J.W. van, Heijke, J.A.M., Raemakers, G.W.M., (1989), Ontwerp van een arbeidsmarktscanner voor academici, ROA-R-1989/3, Maastricht.

Dekker, R.J.P., e.a. (1990), Rapportage I-SEE! 1990, ROA-R-1990/6, Maastricht.

Judge, G.G., e.a. (1980), The theory and practice of econometrics, Canada.

Ministerie van Sociale Zaken en Werkgelegenheid, Schoolverlatersbrief 1990, Rijswijk.

Ramaekers, G.W.M., J.A.M. Heijke (1991), Arbeidsmarktscanner Rijksuniversiteit Limburg. Afgestudeerden 1986-1989, ROA-R-1991/6, Maastricht.

ROA (1991), De arbeidsmarkt naar opleiding en beroep tot 1994, ROA-R-1991/5, Maastricht.

Siegers, J. (1979), Beroepssegregatie tussen mannen en vrouwen in Nederland, in: Economisch Statistische Berichten (ESB), blz. 208-213.

Taakgroep Studentenraming, (1990), Hogeronderwijsraming; deel 1, WORSA, Zoetermeer. 


\section{BIJLAGE I. TABELLEN}

Tabel I. Afgestudeerden geneeskunde, gezondheidswetenschappen, rechten en economie (landelijk en aan de $\mathrm{RL}$ ); totaal absoluut en aandeel van vrouwen

\begin{tabular}{|c|c|c|c|c|c|c|}
\hline & \multicolumn{6}{|c|}{ Historische cijfers } \\
\hline & $1985 / 86$ & $1986 / 87$ & $1987 / 88$ & $1988 / 89$ & $1989 / 90$ & $1990 / 91$ \\
\hline \multicolumn{7}{|l|}{ Geneeskunde } \\
\hline$\%$ Vrouwen NL & 39.15 & 41.63 & 44.5 & 46.02 & 48.32 & 53.41 \\
\hline Totaal NL & 2319 & 2325 & 1881 & 1595 & 1544 & 1144 \\
\hline \% Vrouwen RL & & 44.2 & 33.9 & 57.9 & & \\
\hline Totaal RL & & 77 & 118 & 107 & 140 & 117 \\
\hline \multicolumn{7}{|l|}{ Gezondheidswet. } \\
\hline$\%$ Vrouwen NL & 72.73 & 76.52 & 72.62 & 72.34 & 69.63 & 70.35 \\
\hline Totaal NL & 99 & 115 & 168 & 235 & 438 & 489 \\
\hline$\%$ Vrouwen RL & & 77.7 & 73.7 & 73.9 & & \\
\hline Totaal RL & & 94 & 114 & 111 & 220 & 261 \\
\hline \multicolumn{7}{|l|}{ Economie } \\
\hline$\%$ Vrouwen NL & 7.51 & 9.54 & 11.05 & 14.33 & 16.19 & 18.91 \\
\hline Totaal NL & 1118 & 1373 & 1864 & 2038 & 1871 & 1904 \\
\hline$\%$ Vrouwen RL & & 0 & 11.8 & 31.6 & & \\
\hline Totaal RL & & 0 & 17 & 19 & 47 & 85 \\
\hline \multicolumn{7}{|l|}{ Rechten } \\
\hline$\%$ Vrouwen NL & 36.14 & 38.31 & 40.91 & 42.43 & 43.99 & 45.49 \\
\hline Totaal NL & 2784 & 3054 & 3962 & 3514 & 3960 & 3618 \\
\hline$\%$ Vrouwen RL & & 49.2 & 46.9 & 46.7 & & \\
\hline \multirow[t]{3}{*}{ Totaal RL } & & 122 & 145 & 107 & 172 & 201 \\
\hline & \multicolumn{6}{|c|}{ Prognoses } \\
\hline & $1991 / 92$ & $1992 / 93$ & $1993 / 94$ & $1994 / 95$ & $1999 / 00$ & $2004 / 05$ \\
\hline \multicolumn{7}{|l|}{ Geneeskunde } \\
\hline$\%$ Vrouwen NL & 55.32 & 56.57 & 56.85 & 57.23 & 58.36 & 57.84 \\
\hline Totaal NL & 1128 & 1119 & 1124 & 1141 & 1160 & 1160 \\
\hline Totaal RL & 117 & 117 & 118 & 118 & & \\
\hline \multicolumn{7}{|l|}{ Gezondheidswet. } \\
\hline$\%$ Vrouwen NL & 70.61 & 71.45 & 71.85 & 72.49 & 72.93 & 72.88 \\
\hline Totaal NL & 592 & 683 & 707 & 698 & 713 & 730 \\
\hline Totaal RL & 357 & 440 & 460 & 448 & & \\
\hline \multicolumn{7}{|l|}{ Economie } \\
\hline$\%$ Vrouwen NL & 20.53 & 22.2 & 23.49 & 24.48 & 25.68 & 25.62 \\
\hline Totaal NL & 2226 & 2559 & 2674 & 2655 & 2496 & 2596 \\
\hline Totaal RL & 131 & 195 & 255 & 303 & & \\
\hline \multicolumn{7}{|l|}{ Rechten } \\
\hline$\%$ Vrouwen NL & 47.18 & 48.35 & 49.02 & 49.31 & 50.46 & 50.34 \\
\hline Totaal NL & 3544 & 3638 & 3786 & 3863 & 3928 & 4080 \\
\hline Totaal RL & 218 & 237 & 258 & 269 & & \\
\hline
\end{tabular}

Bron: WORSA, ROA 
$-38-$

Tabel II. Sexediscrepanties in deeltijdwerk; landelijke cijfers

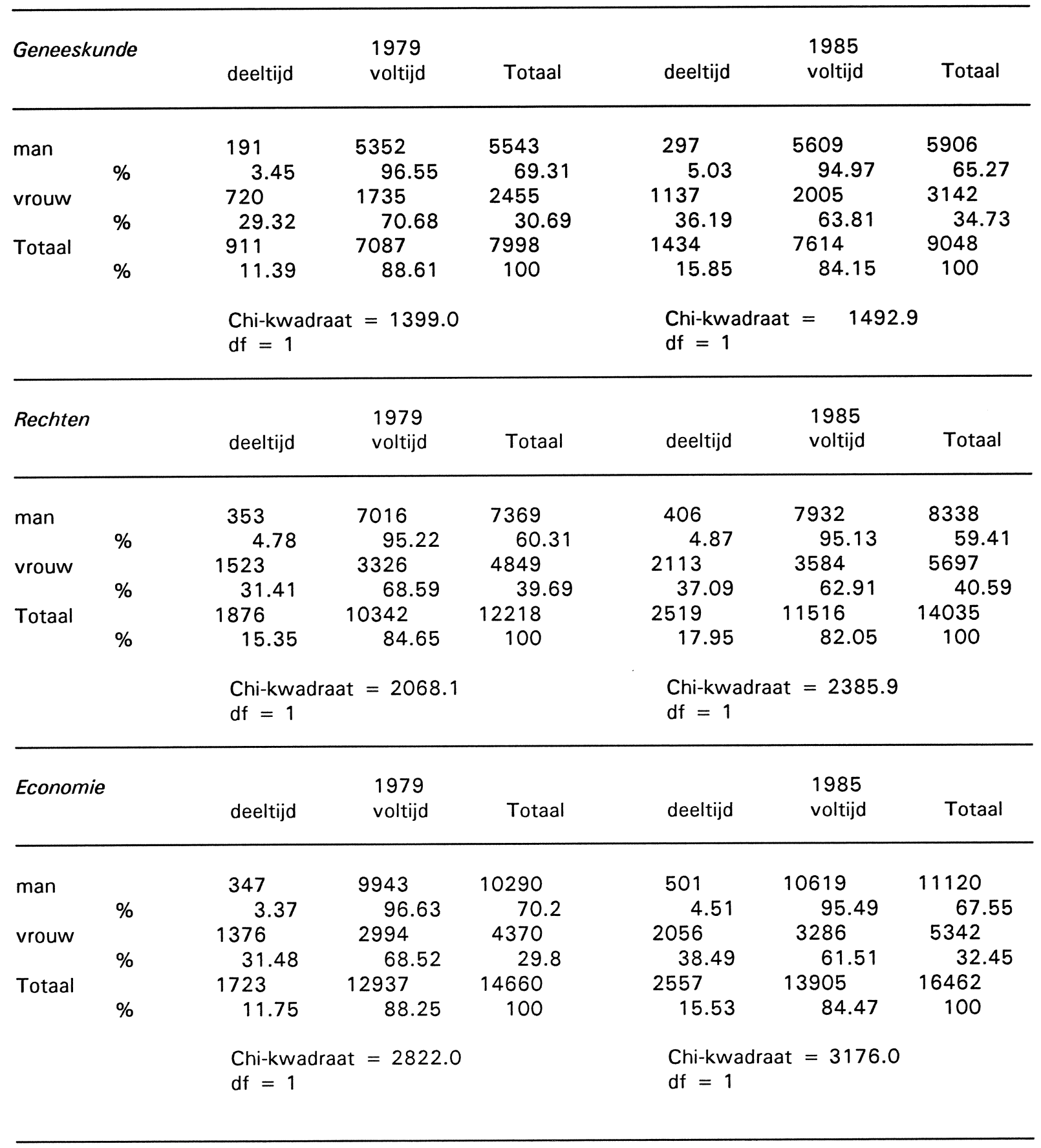

Bron: ROA 
Tabel III. Beroepsklassen per opleidingsrichting naar geslacht in 1985 (in \%)

\section{Geneeskunde}

05 Biomedici, farmacologen, med./biol.analisten

13 Docenten

06/07 Geneeskundigen/verpleegkundigen

19 Wetenschappelijke e.a. vakspecialisten

21 Hoger leidinggevende functies

15 Auteurs/ journalisten

Overig

Totaal N $(=100 \%)$

\subsection{8}

3.2

86.73

1.27

2.8

0.35

3.07

28535

1.63

3.14

2.81

1.32

2.77

15.91

3.43

19.8

5.36

13.22

24.51

0

Hoger leidinggevenden e.d.

Inkopers e.d.

Kunstenaars, fotografen

Zelfst. groothandelaren/tussenpersonen

Overig

0

0.18

5.92

20244

1086

50.28

4.51

3.37

10.5

8.54

3.09

4.06

1.01

2.84

5.14

0.31

0.73

0

0

5.62

60.9

12.02

7.44

1.3

0.83

0.79

5.52

0

0

2.28

1.05

2.38

1.1

1.33

3.06

Overige 
$-40-$

Tabel IV. Relevante arbeidsmarktervaring vóór afstuderen, per faculteit naar geslacht (in \%); meerdere antwoorden mogelijk

\begin{tabular}{|c|c|c|c|c|}
\hline & $\mathrm{FdG}$ & FdGW & $\mathrm{FdR}$ & $\mathrm{RL}$ \\
\hline \multicolumn{5}{|c|}{ Geen werkervaring } \\
\hline Man & 47 & 35 & 52 & 45 \\
\hline Vrouw & 38 & 44 & 54 & 51 \\
\hline Totaal & 54 & 42 & 53 & 48 \\
\hline Chi-kwadraat & $7.2^{*}$ & 2.4 & 0.2 & 3.89 \\
\hline \multicolumn{5}{|c|}{ Werkervaring binnen vakgebied } \\
\hline Man & 22 & 26 & 7 & 0 \\
\hline Vrouw & 23 & 13 & 4 & 0 \\
\hline Totaal & 18 & 24 & 6 & 17 \\
\hline Chi-kwadraat & $4.25^{*}$ & 0.4 & 2.1 & 1.7 \\
\hline \multicolumn{5}{|c|}{ Werkervaring buiten vakgebied } \\
\hline Man & 22 & 27 & 33 & 26 \\
\hline Vrouw & 13 & 15 & 28 & 18 \\
\hline Totaal & 17 & 18 & 31 & 21 \\
\hline Chi-kwdraat & $4.3^{*}$ & $7.6^{*}$ & 0.7 & $11.2^{*}$ \\
\hline \multicolumn{5}{|c|}{ Student-assistenschap } \\
\hline Man & 27 & 37 & 20 & 20 \\
\hline Vrouw & 22 & 37 & 22 & 22 \\
\hline Totaal & 25 & 37 & 21 & 21 \\
\hline Chi-kwadraat & 1.0 & 0.0 & 0.2 & 0.2 \\
\hline \multicolumn{5}{|c|}{ Bestuurservaring } \\
\hline Man & 37 & 37 & 41 & 38 \\
\hline Vrouw & 37 & 32 & 34 & 34 \\
\hline Totaal & 37 & 33 & 38 & 36 \\
\hline Chi-kwadraat & 0.0 & 0.6 & 1.7 & 2.1 \\
\hline (d.f. $=1, X^{2}=$ & & & & \\
\hline
\end{tabular}


Tabel V. Percentage afgestudeerden dat na 1, 3, 6 en 12 maanden betaald werk heeft gevonden, per faculteit naar geslacht

\begin{tabular}{llcccc}
\hline \multirow{2}{*}{ Faculteit } & Geslacht & \multicolumn{4}{c}{ Aantal maanden na afstuderen } \\
& & 1 & 3 & 6 & 12 \\
\hline \multirow{2}{*}{ FdG } & & & & & \\
& man & 38 & 53 & 62 & 71 \\
& vrouw & 34 & 58 & 81 & 91 \\
& totaal & 36 & 55 & 70 & 80 \\
& chi-kwadraat & 0.5 & 0.7 & $14.1^{*}$ & $20.1^{*}$ \\
FdGW & man & 38 & 48 & 51 & 73 \\
& vrouw & 39 & 49 & 61 & 69 \\
& totaal & 38 & 49 & 58 & 70 \\
& chi-kwadraat & 0 & 0 & 2.7 & 0.5 \\
FdR & man & 36 & 42 & 49 & 60 \\
& vrouw & 30 & 35 & 45 & 61 \\
& totaal & 33 & 39 & 48 & 60 \\
& chi-kwadraat & 1.3 & 1.8 & 0.6 & 0 \\
Totaal & man & 40 & 50 & 57 & 69 \\
& vrouw & 36 & 48 & 62 & 72 \\
& totaal & 38 & 49 & 60 & 71 \\
(d.f. $=4, \mathrm{X}^{2}=9.5, \mathrm{p}<0.05$ ) & chi-kwadraat & 1.7 & 0.43 & 2.9 & 1.4 \\
& & & & & \\
\hline
\end{tabular}

$*$ = significant op $5 \%$-niveau 
$-42-$

Tabel VI. Wijze van functieverwerving, per faculteit naar geslacht (in \%)

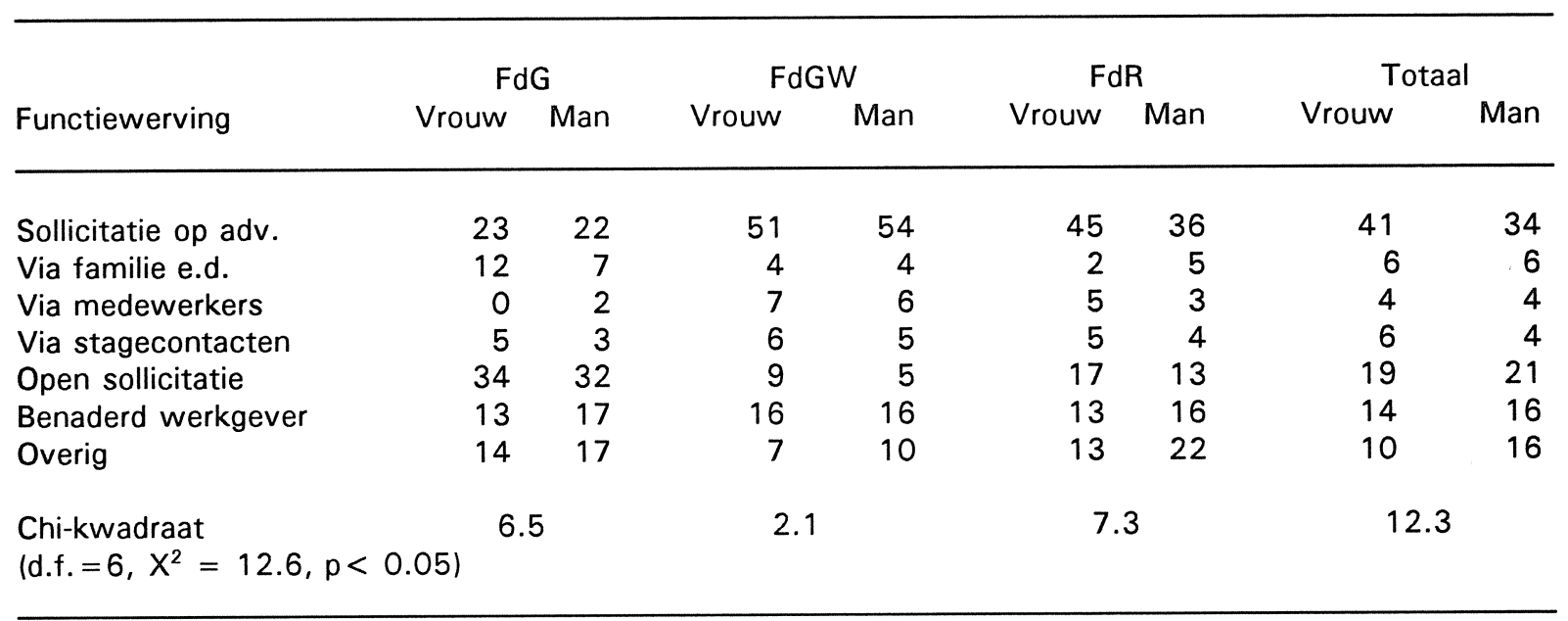

Tabel VII. Percentage respondenten dat als zelfstandige werkzaam is, per faculteit naar geslacht

\begin{tabular}{|c|c|c|c|c|}
\hline Faculteit & Vrouw & Man & Totaal & Chi-kwadraat \\
\hline FdG & 7 & 7 & 7 & 0.1 \\
\hline FdGW & 1 & 0 & 1 & $1.2^{*}$ \\
\hline FdR & 4 & 12 & 8 & $6.4^{*}$ \\
\hline $\mathrm{RL}$ & 3 & 7 & 5 & $7.5 *$ \\
\hline \multicolumn{5}{|c|}{ (d.f. $\left.=1, X^{2}=3.8, p<0.05\right)$} \\
\hline
\end{tabular}

* = significant op $5 \%$-niveau 
$-43-$

Tabel VIII. Percentage respondenten dat in een organisatie werkt met 50 of meer medewerkers, per faculteit naar geslacht

\begin{tabular}{lcrrc}
\hline Faculteit & Vrouw & Man & Totaal & Chi-kwadraat \\
\hline FdG & 64 & 67 & 654 & 0.22 \\
FdGW & 71 & 73 & 71 & 0.05 \\
FdR & 66 & 58 & 62 & 0.15 \\
RL & 68 & 67 & 68 & \\
(d.f. $\left.=1, \mathrm{X}^{2}=3.8, p<0.05\right)$ & & & & \\
\hline
\end{tabular}

Tabel IX. Regio waarbinnen de huidige functie wordt uitgeoefend, per faculteit naar geslacht (in \%)

\begin{tabular}{|c|c|c|c|c|c|c|c|c|}
\hline \multirow[b]{2}{*}{ Regio } & \multicolumn{2}{|c|}{ FdG } & \multicolumn{2}{|c|}{ FdGW } & \multicolumn{2}{|c|}{ FdR } & \multicolumn{2}{|c|}{ RL } \\
\hline & Vrouw & Man & Vrouw & Man & Vrouw & Man & Vrouw & Man \\
\hline Maastricht & 25 & 25 & 23 & 22 & 28 & 36 & 24 & 29 \\
\hline Overig Zuid-Limburg & 17 & 25 & 13 & 17 & 28 & 29 & 18 & 24 \\
\hline Overig Limburg & 10 & 8 & 6 & 3 & 8 & 10 & 8 & 8 \\
\hline Andere provincies & 37 & 31 & 55 & 57 & 35 & 23 & 45 & 35 \\
\hline Buitenland & 11 & 11 & 3 & 3 & 2 & 2 & 5 & 5 \\
\hline Chi-kwadraat & 2. & & 2.0 & & 4.3 & & 11.8 & \\
\hline \multicolumn{9}{|c|}{$\left(\right.$ d.f. $\left.=4, X^{2}=9.5, p<0.05\right)$} \\
\hline
\end{tabular}

* = significant op 5\%-niveau 
Tabel Xa. Basisartsen naar huidig beroep (in \%)

\begin{tabular}{lrrr}
\hline Huidig beroep & Vrouw & Man & Totaal \\
\hline & & 15 & 14 \\
Huisarts & 12 & 2 & 48 \\
Arts-specialist & 1 & 49 & 17 \\
Arts-assistent & 47 & 15 & 4 \\
School-, bedrijfs-, e.d. & 19 & 2 & 7 \\
Sociaal-geneeskundige (bijv. medisch adviseur) & 6 & 7 & 9 \\
Medisch-wetenschappelijk onderzoeker & 7 & 9 & 303 \\
Andere beroepen* & 8 & 158 & \\
Totaal $n$ (=100\%) & 145 & & \\
\hline
\end{tabular}

* Bijvoorbeeld docent, biochemicus, medisch-beleidsmedewerker.

Tabel Xb. Bedrijfssubgroepen waarbinnen tenminste $5 \%$ van de betaald werkende basisartsen werken (in $\%)$

\begin{tabular}{lrrr}
\hline Bedrijfssubgroep & Vrouw & Man & Totaal \\
\hline & & & 20 \\
Algemene, niet-academische ziekenhuizen & 17 & 17 & 17 \\
Academische algemene ziekenhuizen & 17 & 5 & 15 \\
Gespecialiseerde ziekenhuizen (excl. psych.) & 4 & 13 & 9 \\
Huisartsenpraktijken & 16 & 6 & 5 \\
Medische en verpleegkundige diensten, zoals GGD's & 12 & 6 & 503 \\
Wettelijke sociale verzekeringsorganen & 6 & 158 & 30 \\
Universiteiten & 3 & & 5 \\
Totaal n (=100\%) & 145 & &
\end{tabular}


Tabel Xla. Gezondheidswetenschappers naar huidig beroep (in \%)

\begin{tabular}{lrrr}
\hline Huidig beroep & Vrouw & Man & Totaal \\
\hline & & & \\
Medicus (code 617-782) & 18 & 25 \\
Maatschappelijk en cultureel werker & 22 & 9 & 19 \\
Sociaal wetenschappelijk onderzoeker e.d. (code 1921-1927) & 16 & 14 & 15 \\
Beleidsmedewerker (code 2200) & 12 & 11 & 7 \\
Docent e.d. & 6 & 11 & 6 \\
Informatie-analist, econoom (code 832-1102) & 6 & 9 & 5 \\
Administratieve functie & 6 & 5 & 332 \\
& & 252 & 80 \\
\hline
\end{tabular}

Tabel XIb. Bedrijfssubgroepen waarbinnen tenminste $5 \%$ van de betaald werkende gezondheidswetenschappers werken (in \%)

\begin{tabular}{lrrr}
\hline Bedrijfssubgroep & Vrouw & Man & Totaal \\
\hline & & 21 & 20 \\
Universiteiten & 10 & 11 & 21 \\
Algemene ziekenhuizen & 10 & 11 & 10 \\
Overkoepelende organen & 9 & 7 & 8 \\
Med. en verpleegk. diensten & 252 & 80 & 332 \\
Totaal $n(=100 \%)$ & & \\
\hline
\end{tabular}


Tabel Xlla. Juristen naar huidig beroep (in \%)

\begin{tabular}{|c|c|c|c|}
\hline Huidig beroep & Vrouw & Man & Totaal \\
\hline Advocaat & 20 & 16 & 18 \\
\hline Juridisch (beleids)medewerker & 15 & 7 & 11 \\
\hline Juridisch adviseur & 7 & 6 & 6 \\
\hline Bedrijfsjurist & 5 & 4 & 4 \\
\hline Juridisch wetenschappelijk onderzoeker,bijv. AIO & 4 & 4 & 4 \\
\hline Juridisch wetenschappelijk medewerker & 1 & 3 & 2 \\
\hline Jurist, niet eerder genoemd & 10 & 16 & 13 \\
\hline Hoofd afdeling juridische zaken & 0 & 3 & 2 \\
\hline Docent & 11 & 11 & 11 \\
\hline Administratieve functie & 17 & 15 & 16 \\
\hline Andere beroepen* & 3 & 14 & 12 \\
\hline Totaal n (=100\%) & 121 & 135 & 256 \\
\hline
\end{tabular}

* Bijvoorbeeld bedrijfsorganisatiedeskundige, belastingconsulent, bankemployé.

Tabel XIlb. Bedrijfssubgroepen waarbinnen tenminste $5 \%$ van de betaald werkende juristen werken (in \%)

\begin{tabular}{|c|c|c|c|}
\hline Bedrijfssubgroep & Vrouw & Man & Totaal \\
\hline Advokatenkantoren & 19 & 16 & 17 \\
\hline Provincies en gemeenten & 23 & 9 & 16 \\
\hline Universiteiten & 12 & 16 & 14 \\
\hline Pensioenfondsen & 6 & 5 & 5 \\
\hline Totaal $n(=100 \%)$ & 121 & 135 & 256 \\
\hline
\end{tabular}




\section{BIJLAGE II. DEFINITIE VAN ENDOGENEN EN EXOGENEN IN DE MULTIVARIATE ANALYSES}

De endogenen 'Baanzekerheid' tot en met 'Externe mobiliteit' hebben alleen waarden indien de 'Huidige maatschappelijke situatie' gelijk aan 1 is.

\begin{tabular}{|c|c|c|}
\hline Endogenen & Vaarden & Betekenis \\
\hline Huidige maatschappelijke situatie & $\begin{array}{l}0 \\
1\end{array}$ & $\begin{array}{l}\text { geen betaalde baan } \\
\text { wel een betaalde baan }\end{array}$ \\
\hline Baanzekerheid & $\begin{array}{l}0 \\
1\end{array}$ & $\begin{array}{l}\text { geen vaste aanstelling } \\
\text { wel een vaste aanstelling }\end{array}$ \\
\hline Werktijdfactor & $\begin{array}{l}0 \\
1\end{array}$ & $\begin{array}{l}\text { geen full-time baan } \\
\text { wel een full-time baan }\end{array}$ \\
\hline Leidinggeven & $\begin{array}{l}0 \\
1\end{array}$ & $\begin{array}{l}\text { geen leidinggevende functie } \\
\text { wel een leidinggevende functie }\end{array}$ \\
\hline $\begin{array}{rl}f & 15 \\
f & 17 \\
f & 22 \\
f & 27 \\
f & 33 \\
f & 43 \\
f & 62 \\
f & 10.0\end{array}$ & $\begin{array}{l}500,-- \\
750,-- \\
250,-- \\
750,-- \\
375,-- \\
375,-- \\
250,-- \\
000,--\end{array}$ & $\begin{array}{c}\text { klassemidden } \\
" \\
" \\
" \\
" \\
" \\
" \\
"\end{array}$ \\
\hline Opleidingseisen & $\begin{array}{l}0 \\
1\end{array}$ & $\begin{array}{l}\text { WO-niveau niet vereist } \\
\text { WO-niveau wel vereist }\end{array}$ \\
\hline Aanvullende opleiding & $\begin{array}{l}0 \\
1\end{array}$ & $\begin{array}{l}\text { geen aanvullende opleiding } \\
\text { wel een aanvullende opleiding }\end{array}$ \\
\hline Baanmobiliteit & $\begin{array}{l}0 \\
1\end{array}$ & $\begin{array}{l}\text { niet van werkgever veranderd } \\
\text { wel van werkgever veranderd }\end{array}$ \\
\hline Potentiële baanmobiliteit & $\begin{array}{l}0 \\
1\end{array}$ & $\begin{array}{l}\text { niet op zoek naar ander werk } \\
\text { wel op zoek naar ander werk }\end{array}$ \\
\hline Exogenen & Naarden & Betekenis \\
\hline $\begin{array}{l}\text { Afstudeerrichting: } \\
\text { Geneeskunde }\end{array}$ & $\begin{array}{l}1 \\
0\end{array}$ & $\begin{array}{l}\text { indien respondent geneeskunde studeerde } \\
\text { anders }\end{array}$ \\
\hline BB (Beleid en Beheer) & $\begin{array}{l}1 \\
0\end{array}$ & $\begin{array}{l}\text { indien respondent BB studeerde } \\
\text { anders }\end{array}$ \\
\hline GVO (Gezondheidsvoorlichting en -opvoeding) & $\begin{array}{l}1 \\
0\end{array}$ & $\begin{array}{l}\text { indien respondent GVO studeerde } \\
\text { anders }\end{array}$ \\
\hline
\end{tabular}


$-48-$

Exogenen

Waarden Betekenis

VW (Verplegingswetenschap)

1 indien respondent VW studeerde

0 anders

Geslacht

$0 \quad$ Vrouw

1 Man

Leeftijd

$20, . . \quad$ Leeftijd op moment van bevraging

Werkervaring

1 wel betaalde werkervaring opgedaan vóor

afstuderen

0 geen betaalde werkervaring opgedaan vóor afstuderen

Bestuurservaring

1 wel bestuurservaring opgedaan vóór

afstuderen

0 geen bestuurservaring opgedaan vóor afstuderen

Bedrijfsomvang

$1 \quad$ meer dan 99 werknemers

$0 \quad 99$ of minder werknemers

Cohort

$1,2,3,4$ aantal jaren afgestudeerd

Profit

$1 \quad$ werken in profit-sector

0 werken in overige sectoren

Combi

$1 \quad$ werken combineren met leren

0 werken niet combineren met leren 
$-49-$

BIJLAGE III. SCHATTINGSRESULTATEN VAN DE MULTIVARIATE ANALYSES

\begin{tabular}{lcc}
\hline & \multicolumn{2}{c}{ Huidige matschappelijke positie } \\
Variabele & parameter & t-waarde \\
\hline Afstudeerrichting: & & 1.35 \\
Geneeskunde & 0.25 & 1.13 \\
BB & 0.25 & -1.93 \\
GVO & -0.43 & -1.22 \\
VW & -0.29 & -2.41 \\
Rechten & $-0.42^{*}$ & 2.15 \\
Economie & $0.75^{*}$ & -1.91 \\
Geslacht & -0.19 & -0.9 \\
Leeftijd & -0.01 & 2.87 \\
Werkervaring & $0.29^{* *}$ & -0.61 \\
Bestuurservaring & -0.06 & 6.81 \\
Cohort & $0.37^{* *}$ & 1.69 \\
Constante & 0.46 & \\
\hline
\end{tabular}

* = significant op $5 \%$ niveau

* * = significant op $1 \%$ niveau

\begin{tabular}{|c|c|c|c|c|}
\hline \multirow[b]{2}{*}{ Variabele } & \multicolumn{2}{|c|}{ Baanzekerheid } & \multicolumn{2}{|c|}{ Werktijdfactor } \\
\hline & parameter & t-waarde & parameter & t-waarde \\
\hline \multicolumn{5}{|l|}{ Afstudeerrichting: } \\
\hline Geneeskunde & -0.35 & -1.67 & 0.04 & 0.14 \\
\hline BB & $0.44^{*}$ & 1.98 & 0.25 & 0.81 \\
\hline GVO & -0.29 & -1.04 & -0.10 & -0.31 \\
\hline VW & 0.34 & 1.33 & -0.09 & -0.27 \\
\hline Rechten & 0.22 & 1.08 & 0.21 & 0.72 \\
\hline Economie & $1.06 * *$ & 3.78 & -0.66 & -1.48 \\
\hline Geslacht & 0.14 & 1.27 & 0.49 & 3.55 \\
\hline Leeftijd & 0.01 & 0.73 & $-0.07 * *$ & -4.86 \\
\hline Werkervaring & -0.20 & -1.85 & $0.29 *$ & 2.19 \\
\hline Bestuurservaring & 0.06 & 0.59 & -0.03 & -0.23 \\
\hline Cohort & 0.03 & 0.62 & 0.07 & 1.22 \\
\hline Profit & & & $0.88 * *$ & 4.43 \\
\hline Combi & & & $0.83 * *$ & 4.33 \\
\hline Constante & $-1.16 * *$ & -3.41 & $2.05 * *$ & 4.92 \\
\hline
\end{tabular}

* = significant op $5 \%$ niveau

** = significant op $1 \%$ niveau 


\begin{tabular}{|c|c|c|c|c|}
\hline \multirow[b]{2}{*}{ Variabele } & \multicolumn{2}{|c|}{ Leidinggeven } & \multicolumn{2}{|c|}{ Inkomen } \\
\hline & parameter & t-waarde & parameter & t-waarde \\
\hline \multicolumn{5}{|l|}{ Afstudeerrichting: } \\
\hline Geneeskunde & 0.25 & 0.99 & $984.57 * *$ & 5.49 \\
\hline BB & -0.07 & -0.24 & $417.45^{*}$ & 2.06 \\
\hline GVO & 0.03 & 0.10 & 24.47 & 0.11 \\
\hline VW & -0.10 & -0.33 & 140.48 & 0.62 \\
\hline Rechten & -0.08 & -0.31 & 65.14 & 0.37 \\
\hline Economie & 0.17 & 0.43 & 18.64 & 0.07 \\
\hline Geslacht & $0.26^{*}$ & 2.40 & $266.05 * *$ & 2.89 \\
\hline Leeftijd & 0.03 & 0.26 & & \\
\hline Werkervaring & $0.27^{*}$ & 2.39 & & \\
\hline Bestuurservaring & -0.05 & -0.43 & & \\
\hline Cohort & $0.25 * *$ & 4.94 & $216.69 * *$ & 4.92 \\
\hline Baanzekerheid & & & $454.19 * *$ & 4.16 \\
\hline Werktijdfactor & & & 85.04 & 0.77 \\
\hline Leidinggeven & & & $498.14^{* *}$ & 5.04 \\
\hline Opleidingseisen & & & $304.38^{*}$ & 2.56 \\
\hline Baanmobiliteit & & & 77.55 & 0.86 \\
\hline Bedrijfsomvang & & & $229.83 * *$ & 2.61 \\
\hline Profit & 0.11 & 0.73 & 10.29 & 0.09 \\
\hline Combi & -0.11 & -0.76 & $-828.86^{* *}$ & -6.49 \\
\hline Constante & $-2.38 * *$ & -6.38 & $2318.89 * *$ & 11.23 \\
\hline
\end{tabular}

* = significant op $5 \%$ niveau

** = significant op $1 \%$ niveau
Gecorrigeerde R kwadraat Standaard fout

$F$ waarde
0.22

1151.62

$14.31 *$ 


\begin{tabular}{lcccc}
\hline Variabele & \multicolumn{2}{c}{$\begin{array}{c}\text { Opleidingseisen } \\
\text { parameter }\end{array}$} & t-waarde & \multicolumn{2}{c}{$\begin{array}{c}\text { Aanvullend onderwijs } \\
\text { parameter }\end{array}$} & t-waarde \\
\hline Afstudeerrichting: & & & & \\
Geneeskunde & $1.26^{* *}$ & 3.67 & 0.31 & 0.77 \\
BB & 0.22 & 0.75 & -0.03 & -0.09 \\
GVO & -0.20 & -0.64 & -0.12 & -0.27 \\
VW & -0.30 & -0.96 & 0.36 & 1.37 \\
Rechten & 0.37 & 1.38 & $1.29^{* *}$ & 2.57 \\
Economie & 0.15 & 0.37 & -0.24 & -1.71 \\
& & & $-0.03^{*}$ & -2.36 \\
Geslacht & -0.05 & -0.32 & -0.14 & -0.97 \\
Leeftijd & -0.01 & -0.57 & $0.49^{* *}$ & 3.39 \\
Werkervaring & 0.16 & 1.17 & & \\
Bestuurservaring & 0.14 & 1.02 & & \\
Cohort & 0.02 & 0.33 & & \\
Profit & $-0.44^{* *}$ & -2.97 & & \\
Combi & $1.21^{* *}$ & 2.91 & & \\
Constante & 0.78 & 1.87 & & \\
\hline
\end{tabular}

* = significant op $5 \%$ niveau

* * = significant op $1 \%$ niveau 


\begin{tabular}{|c|c|c|c|c|}
\hline \multirow{2}{*}{ 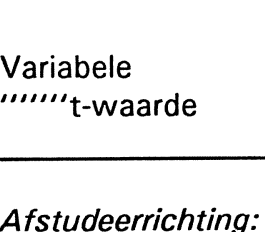 } & \multirow[t]{2}{*}{$\begin{array}{l}\text { Baanmobiliteit } \\
\text { parameter }\end{array}$} & \multirow[t]{3}{*}{$t$-waarde } & \multicolumn{2}{|c|}{$\begin{array}{l}\text { Potentiële baanmobiliteit } \\
\text { parameter }\end{array}$} \\
\hline & & & & \\
\hline & & & & \\
\hline $\begin{array}{l}\text { Geneeskunae } \\
\text { BB }\end{array}$ & $1.01 \times$ & 5.52 & 0.10 & \\
\hline & $0.49 *$ & 2.43 & -0.29 & -1.06 \\
\hline GVO & 0.35 & 1.57 & -0.16 & -0.55 \\
\hline VW & $0.66 * *$ & 2.96 & -0.28 & -0.93 \\
\hline Rechten & $0.46^{*}$ & 2.52 & -0.06 & -0.23 \\
\hline Economie & -0.50 & -1.53 & & \\
\hline Geslacht & -0.06 & -0.66 & -0.02 & -0.14 \\
\hline Leeftijd & -0.01 & -0.60 & & \\
\hline Werkervaring & -0.04 & -0.41 & & \\
\hline Bestuurservaring & 0.09 & 1.02 & & \\
\hline Cohort & & & -0.01 & -0.22 \\
\hline Baanzekerheid & & & $-0.30^{*}$ & -2.09 \\
\hline Werktijdfactor & & & -0.24 & -1.63 \\
\hline Inkomen & & & -0.06 & -1.64 \\
\hline Leidinggeven & & & 0.23 & 1.91 \\
\hline Aansluiting & & & $-0.24 * *$ & -2.92 \\
\hline Profit & & & -0.27 & -1.73 \\
\hline Combi & & & $-0.87 * *$ & -5.20 \\
\hline Constante & -0.55 & -1.83 & 0.55 & 1.64 \\
\hline
\end{tabular}

* = significant op $5 \%$ niveau

** = significant op $1 \%$ niveau 